\title{
Os casamentos árabes: a recriação de tradições entre imigrantes palestinos no Sul do Brasil
}

Denise Fagundes Jardim*

Roberta Peters**

Resumo. O artigo reúne os resultados produzidos em dois campos de pesquisa a cidade de Chuí e grande Porto Alegre, RS -, explorados por meio do método etnográfico. O objetivo é evidenciar o empenho dos imigrantes em recriar tradições árabes e sublinhar práticas sociais comuns, extraindo do terreno da vida ordinária elementos que são elevados à categoria de signo emblemático da própria coletividade. Desde a publicação da coletânea $A$ Invenção das Tradições de Ranger \& Hobsbawn em 1983, discorrer sobre "tradições" não é um exercício de mera descrição. Retomamos o debate sobre a invenção e recriação das tradições a partir da análise dos rituais de casamento e da centralidade dessas festas de casamento na fabricação de uma coesão social.

Palavras-chave: Palestinos. Tradição. Gênero.

\footnotetext{
* Antropóloga e Professora do Departamento de Antropologia e PPGAS/UFRGS. ** Licenciada em Ciências Sociais pela UFRGS e Mestranda em Antropologia no PPGAS/UFRGS.
}

Anos 90, Porto Alegre, v. 12, n. 21/22, p.173-225, jan./dez. 2005 
Os casamentos árabes: a recriação de tradições entre imigrantes...

Existe um circuito de festas de casamento no Rio Grande do Sul muito apreciado pelos imigrantes de origem árabe. É o momento em que as famílias escolhem quem irão levar para a festa e, desta maneira, quais os filhos que potencialmente estarão disponíveis ao mercado matrimonial. Os próprios entrevistados esfregam as mãos e brincam que as festas de casamento são um momento em que "os árabes fazem negócios", referindo-se a conhecer suas potenciais cônjuges já tendo alguma idéia sobre quem são as famílias que encontrarão nas festas, sua procedência, de qual cidade ou família.

O objetivo deste artigo é o de reunir os resultados obtidos em pesquisas etnográficas desenvolvidas em dois universos distintos. ${ }^{1}$ Um primeiro universo se refere à observação das famílias de origem árabe que residem no extremo sul do Brasil, na fronteira entre Uruguai e Brasil, e um estudo seguinte relaciona-se às famílias que vivem em cidades próximas a Porto Alegre. Portanto, há duas autoras e duas etnógrafas com campos de observação que se conectam em diferentes aspectos.

O fio condutor de nossa exposição é tecido em torno do debate da invenção das tradições por parte de imigrantes de origem árabe e da centralidade das festas de casamento em evidenciar e tornar públicas o que seriam as "tradições" de um grupo. Primeiramente, é necessário retomar algumas considerações sobre o que entendemos como "tradições" e sobre a reinvenção das tradições. Este debate não é exclusivo da antropologia ou da história, mas tem desdobramentos e usos diferenciados nas disciplinas.

O texto deve ser lido com cuidado porque o detalhe não é fortuito. Sempre que utilizamos a terceira pessoa do plural, evidenciamos uma convergência de interpretações das autoras, aspectos que partilhamos. Os dois universos de pesquisa, embora realizados em momentos e por etnógrafas diferentes, tem a sua conexidade. Foi inicialmente no Chuí que, a partir dos entrevistados, soubemos da possibilidade de conhecer as famílias Baja e

Anos 90, Porto Alegre, v. 12, n. 21/22, p.173-225, jan./dez. 2005 
Backi que residem em nosso segundo campo de observação, qual seja, em Porto Alegre e região denominada "Grande Porto Alegre”. Essas famílias, indicadas como centrais, indispensáveis pelos entrevistados, permitiam aos entrevistados no Chuí recordar as festas de casamento a que foram convidados e as suas próprias festas, aquelas que tinham promovido para os seus filhos ou realizadas na sua parentela. No Chuí, evidenciavam a importância das famílias residentes em Canoas, qualificando-as como as mais importantes no circuito de relações entre imigrantes no Sul do Brasil.

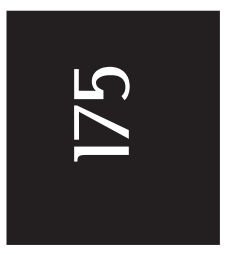
No ano de 2002, iniciamos o mapeamento dessa ampla rede de interconhecimento no Sul do Brasil, começando por aquilo que era enunciado como seu centro.

O tema dos rituais e festas de casamento manteve-se um assunto recorrente porque era relatado como absorvente para os investigados e intrigante para nós. Caberia explorar tanto os aspectos comuns, entre os dois universos de pesquisa, explorando por que tal assunto é tão atraente para os investigados, mas também realçando suas singularidades. Com certeza, para falar sobre a experiência dos imigrantes de origem árabe é necessário mais de um artigo. $\mathrm{O}$ que faremos aqui é explicitar um eixo comum que nos leva a refletir sobre os casamentos e festas de casamento, evidenciando sua centralidade na reinvenção das tradições árabes desse grupo imigrante.

Desde a publicação da coletânea $A$ Invenção das Tradições, de Ranger \& Hobsbawn, em 1983, discorrer sobre "tradições" não é um exercício de mera descrição. Mesmo que não haja uma exigência em se datar e evidenciar a ancestralidade de certas práticas, o debate sobre tradições está permeado pela dúvida e pela suspeita. De um lado, elas não seriam tão antigas quanto se encenam; de outro, não seriam tão verossímeis quanto desejam aparentar. De fato, as propostas de Hobsbawn transbordaram seus próprios objetivos e acabaram influenciando uma postura crítica que suspeita das tradições. Tal postura a constrói como uma "farsa" histórica 
Os casamentos árabes: a recriação de tradições entre imigrantes...

permeada por interesses em jogo que, ao fim, destituiriam o valor das "verdadeiras tradições". Embora isso não seja mais uma interpretação proposta pelo autor da coletânea, reflete um uso bastante corrente do termo. A tradição tem sugerido que haveria, em algum lugar, um costume verdadeiro alheio aos interesses e jogos políticos. O ofício de historiador, e mesmo dos antropólogos, se pautaria por desmascarar as engrenagens de uma invenção. Desta perspectiva somos igualmente levados a imaginar que uma tradição verdadeira se rompera ou nem mesmo existira.

Deve-se lembrar que, no programa de estudos de Hobsbawn, o foco recai na análise da Era das nações e inspeciona sua construção histórica. Os Estados-nações produziram imagens e um ideário que os eternizam, seja na sua existência política ou no que tange aos costumes, a rotinização de hábitos, reconhecidos como próprios "de um povo". Caberia ao historiador analisar qual a complexa engenharia social que ajudara a produzir uma "coesão social" e, por meio de jogos de imagens e rituais públicos, evidenciar como havia sido consagrada uma simbologia nacional extensiva a uma nação. Esta nação, imaginada com origens remotas mas vista como algo extremamente atual, estaria projetando uma continuidade dessa tradição no futuro.

Tal perspectiva fornecia uma chave para averiguar a produção de uma coesão social tomando o nacionalismo como um idioma fundamental dessa comunização e da projeção de uma modernidade sobre aspectos tidos e vistos como ancestrais ou antigos. ${ }^{2} \mathrm{O}$ período pós-colonial fornecera os ingredientes necessários para a circulação de sentimentos nacionalistas e dessas invenções. Os conflitos e rearranjos políticos no século XX permitiam verificar a força política dos nacionalismos como a forma contemporânea de inventar tradições e produzir novos contornos a coletividades como "unidades políticas" e inscrevê-las como "eternas". 
No jogo entre o "antigo" e o "novo", entre o que é sublinhado como "tradição" e o que é visto como "novidade", o termo "invenção" tem semanticamente escorregado para outro campo de debates, o debate sobre a existência (ou não) de uma "verdadeira" tradição. Na perspectiva proposta por Hobsbawn, a análise desse passado reconstruído nos daria acesso a demandas e movimentos políticos. A proposta nos permite questionar aspectos que são tidos e vistos por seus protagonistas como imutáveis. Analiticamente, o autor nos evidencia que a continuidade histórica é sem-

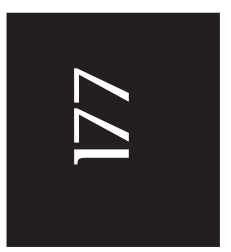
pre um esforço coletivo. Frente a disputas e jogos sociais em eternizar determinadas características e sublinhar práticas sociais comuns, alguns grupos e coletividades extraem do terreno "ordinário" elementos que podem ser elevados à categoria de signo emblemático de algo, de alguém ou da própria coletividade. Não é mais um mero costume, mas um costume digno de nota. Por intermédio dele, uma unidade política ou cultural está sendo configurada e um "nós" coletivo é evidenciado.

Ao final de sua introdução, Hobsbawn conclama historiadores e antropólogos a refletir sobre os processos sociais que nos permitem transformar nações e Estados-nações em realidades dotadas de permanência, acima do tempo e do espaço. Dessa maneira, não estaríamos tão somente debatendo a invenção das tradições e denunciando sua fragilidade enquanto produtos históricos. A proposta remete à investigação da invenção de sentimentos relacionados à fabricação da coesão social e de todos os artifícios que os grupos humanos se utilizam para produzir noções, mais ou menos duradouras, de uma coletividade dotada de uma origem comum e destinos tangíveis.

É necessário evitar transpor uma discussão sobre a "invenção das tradições", marcadas pelo debate sobre Estados-nacionais, para uma outra escala, sem fazer os devidos ajustes. Duvidar da autenticidade das propostas de "state-makers" que têm um lugar de fala autorizado e uma posição no jogo político é algo bem 
Os casamentos árabes: a recriação de tradições entre imigrantes...

diferente da dúvida que recai sobre pessoas que manejam um capital simbólico e social diferenciado. Muitas vezes, os sujeitos em questão ocupam lugares desvantajosos no embate político e são desautorizados sequer a proclamar sua simples existência e relevância social.

A polêmica fora recentemente debatida por Sahlins (2001), retomando reflexões sobre o uso do termo "tradição inventada" e os pressupostos e dúvidas sobre a autenticidade das práticas dos nativos. Afinal, o que é uma tradição? Com certeza é um tema caro aos antropólogos e, por vezes, a própria definição de seu ofício. Caberia ao antropólogo um exercício de mera descrição de aspectos tradicionais? Sahlins assim como Alban Bensá (1996) e Barth (2000) tendem a criticar a operacionalidade dos conceitos de cultura e tradição quando são tomados como instrumentos de descrição que fossilizam as práticas dos nativos. ${ }^{3}$

Os processos históricos têm sido objeto de reflexão por parte de distintas disciplinas das ciências sociais, principalmente no que toca à discussão sobre o conceito de cultura. Até a década de 70, a idéia da cultura como uma totalidade integrada e coesa permeava o trabalho dos antropólogos. Assim, os aspectos diacrônicos pensados no âmbito das teorias sobre etnicidade e, conseqüentemente, o papel da tradição, foram elaborados a partir de uma noção de cultura entendida como um substrato, um fundo comum, algo substancial. O conceito de "aculturação" vicejou a partir dessa perspectiva. Possibilitava identificar processos e dinâmicas culturais e fornecer modelos de análise a partir de um conceito de cultura em que algo poderia ser "adquirido" e "perdido" em uma presumida totalidade.

Assumindo as propostas de Weber (1968), por exemplo, a discussão sobre grupos étnicos pode convergir a uma bem-vinda crítica às noções de cultura marcadas por um essencialismo. Mesmo assim, a crítica ao essencialismo e noções de "totalidade" não é inteiramente abandonada, mesmo se se adota uma perspectiva 
Denise Fagundes Jardim \& Roberta Peters

instrumental para o entendimento dos sentimentos étnicos. A fabricação de sentimentos de pertencimento a um grupo que supõe uma "mesma origem", é vista comumente como uma retórica e, dessa maneira, um sentimento manipulado e instrumental.

Nossa proposta é suspender a "suspeita". Queremos revisitar a dúvida quanto à força dos sentimentos étnicos por meio de uma situação social observada. Percebemos um uso social difuso, com múltiplas direções, daquilo que consideramos o sentimento étnico. Certamente não podemos descrevê-lo como um mero instaurador

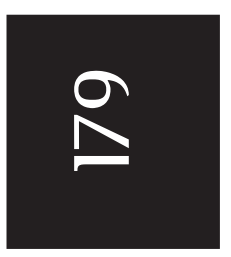
de uma unidade social, de um grupo, pois atua em múltiplas direções. Talvez aí resida sua força e sua constante atualização, pois o eixo fundamental não é sua veracidade. A força dos sentimentos étnicos, assim como a força da retórica das tradições, age em múltiplos campos da vida social. Não se define por sua duração no tempo ou antigüidade, mas pelo sentido de coesão social que consegue propiciar. Muitas vezes, essa coesão se traduz em uma "lógica própria" que o grupo atualiza; outras vezes, essa coesão social transparece em momentos rituais. Para nós, é algo que anima as relações sociais.

Nas últimas décadas, uma vertente pós-moderna na antropologia se opôs radicalmente à compreensão da noção de cultura por um viés essencialista. A descrição de códigos culturais tem mostrado a urgência em apresentar sua feição dinâmica, considerando que distintos aspectos podem ser reinventados, ressemantizados e forjados em determinados contextos de conflito e jogo social. Esse caráter instrumental da cultura estende-se a noções de tradição. Como sugere Manuela Carneiro da Cunha (1986), num processo de produção de contrastes os grupos tomam da tradição elementos de sua bagagem cultural que são operativos e estratégicos, que irão garantir a distinção do grupo enquanto tal na sociedade em que estão inseridos. Se, por um lado, a idéia de cultura como uma totalidade harmônica substancial ossificava os sujeitos na tradição, a discussão atual opera num princípio político 
Os casamentos árabes: a recriação de tradições entre imigrantes...

inverso, destituindo-os de uma identidade singular. Em que pese o valor político do discurso acadêmico, Carneiro da Cunha (2003) acrescenta que a fala sobre a cultura deve ser reconhecida pelos antropólogos não como uma ilusão, já que agora tudo parece ser inventado, mas como formas de conhecer e representar o mundo vivido como realidade.

Tal "suspeita" sobre a tradição, ou sobre a cultura de um grupo, tem-se configurado em um lugar de debate político. Tudo se passa como se os atores não vivenciassem sua cultura como autêntica e substancial, já que os antropólogos lembram o tempo todo o quanto ela é forjada. O conceito de cultura, por exemplo, tem sido debatido e opera simultaneamente em dois níveis. Conforme Carneiro da Cunha, ele opera em um nível literal que concebe cultura como algo que informa valores e ações de forma dinâmica e mutável, e num nível político.

Para efeitos de nossa exposição, consideramos que o costume e a tradição para os palestinos é uma criação deles próprios a partir de um vasto acervo cultural constituído na experiência de diáspora. ${ }^{4}$ As festas de casamento são um contexto privilegiado para entender quais os sinais diacríticos significantes na construção da identidade étnica. $\mathrm{Na}$ descrição que se segue, buscamos dar inteligibilidade à sobreposição de significados e sentidos possíveis que os investigados produzem ao tecer em detalhe e com muito envolvimento aqueles que seriam os aspectos relevantes que definem a sua "tradição" e a possibilidade de atualizá-la para seus filhos.

Como não estão "ameaçados" por um discurso político que os denunciaria como "imitação" ou "falsificação", nossa observação torna-se mais fluída e faz-se ao sabor de suas próprias reflexões, conflitos e certezas sobre as tradições. ${ }^{5}$ Evidentemente, nem todos os trabalhos de campo sobre identidade étnica são beneficiados por tal situação. Por vezes, os simples desacordos ou a diversidade de modos de fazer que encontramos na vida social 
credenciam agentes políticos, contrários ou exteriores ao campo, a formular discursos que desautorizam os entrevistados a falar sobre si e sobre a veracidade de sua própria experiência social.

$\mathrm{Na}$ primeira parte deste artigo, apresentamos algumas indagações sobre os casamentos árabes e como essa tradição é recriada por imigrantes e seus filhos no Chuí. Queremos mostrar a descoberta de um modo singular de pensar a "família árabe" e de refletir sobre seus "modelos ideais". Na segunda parte do texto, descrevemos as festas de casamento como um ritual revelador de outros aspectos desse ethos e que coloca em jogo diversos discursos sobre a origem frente aos nacionais e aos próprios "patrícios", 6 observando os imigrantes que vivem na Grande Porto Alegre. As duas partes conjugam etnografias sobre "bastidores" (das decisões que envolvem ir às festas de casamento) e sobre um determinado "palco" (a festa de casamento) em que ocorre uma exposição pública sobre a identidade étnica e sobre as tradições recriadas por imigrantes no Sul do Brasil.

\section{Os casamentos arranjados: um campo de debate sobre a família árabe e seus significados}

Este tópico está centrado na etnografia sobre os imigrantes de origem palestina que vivem no extremo sul do Brasil. O primeiro contato com o universo de pesquisados foi feito por intermédio das prefeituras de Santa Vitória do Palmar. Os "locais" falavam de seu estranhamento com relação ao exotismo dos imigrantes "árabes", vistos por eles como "turcos". Iniciei o trabalho de campo diante de uma fronteira simbólica já sedimentada por experiências prévias entre os "nossos" e os "outros". Esta fronteira era trazida à tona por sinais diacríticos referidos à nacionalidade (estrangeira), manejo de idiomas diversos, modos singulares de vestir e agir. Referia-se a uma experiência direta de relacionamentos 
Os casamentos árabes: a recriação de tradições entre imigrantes...

travados no comércio, mais do que por qualquer diferença religiosa.

Nesse contexto, a nacionalidade é uma negociação constante. A cidade do Chuí e sua gêmea uruguaia Chuy são cidades contíguas. Há, no "lado brasileiro" e no "lado uruguaio", muitas distinções quanto à antigüidade da cidade e dos serviços oferecidos pelas municipalidades. O Chuí é retratado como um lado mais precário em termos de oferta de escolarização e atendimento de saúde. Entretanto, a vida social está emaranhada e atravessa esses "lados" com a maior desenvoltura. É certo que em um lugar no qual os símbolos nacionais estão constantemente em cena, em que as relações sociais referem a origem nacional ou regional, esse é um idioma por excelência de classificação das pessoas. Uma referência que serve tanto para situá-las na interlocução quanto para desqualificá-las. Em que pese a circulação de moedas nacionais dos dois países e o fato de o bilingüismo ser algo peculiar, falar a língua do outro não é uma regra para todos, mas é muito comum aos imigrantes de origem árabe. Os imigrantes de origem árabe, em sua maioria, desenvolvem a atividade comercial. É necessário negociar.

Denominações como árabe, palestino, jordaniano, sudanês, egípcio, uruguaios, brasileiros, argentinos, paulistas, cearenses são princípios de divisão da realidade. Isso ocorre não só diante do pesquisador, mas para qualquer interlocutor. Por vezes, as pressuposições de uma origem comum acabam banalizando o tema, o próprio sotaque já é um indicador que resume e classifica quem é o sujeito, independente da explicitação de sua própria trajetória. Os "turcos", como são denominados, constituem uma classificação muito usual, atribuída pelos locais aos imigrantes oriundos do oriente médio. Inicialmente, poucos se interessam em compreender toda a complexidade do itinerário desses imigrantes. E, de outra parte, os imigrantes já estão acostumados a explicar de uma maneira muito didática que não são turcos. Além dessa presumida "unidade 
Denise Fagundes Jardim \& Roberta Peters

de procedência", os imigrantes estão em sua maioria no comércio, em uma região em que predomina a atividade rural ligada ao cultivo do arroz e ao trabalho nas granjas. Todas essas características acabam reforçando a idéia de que meus entrevistados, vistos de fora, são "um grupo muito fechado", seja por sua homogeneidade a priori, seja pelo desconhecimento de suas histórias pessoais.

Entre tantos indicadores de diferenças, lembro que chamoume a atenção de que era quase uma "queixa". Deles era dito que "até podiam namorar brasileiras, mas acabavam casando com árabes". Seguindo essas acusações de ordem moral que recaíam sobre o "grupo", havia aquelas em que as brasileiras eram retratadas como noivas "enganadas". Nessas falas, "exteriores" ao grupo, revelavam-se os temores sobre o grau de confiança que era depositado nas relações e nos negócios com os "turcos", e ressaltavase uma fronteira assinalada nos "costumes". De fato, eram estereótipos produzidos por uma relação próxima e necessária entre imigrantes e "locais".

Mais do que averiguar a veracidade das acusações, me chamava atenção a pressuposição de uma fronteira entre modos de agir. O trabalho resultou em algo mais amplo, do qual recorto aqui apenas os aspectos relativos aos casamentos "entre os seus". Ao fim e ao cabo, o tema dos casamentos é apenas uma das diversas entradas possíveis para compreender as fronteiras simbólicas tecidas na experiência desse grupo minoritário.

Como entender a afirmação de que eles preferem "casar entre os seus"? Primeiro, os casamentos eram um assunto central. A primeira opção era averiguar a veracidade dessas atribuições ou acusações. Os fatos, comprovados ou não, me conduziam a desvendar o "ponto de vista dos nativos" e revelavam o drama das escolhas matrimoniais nesse contexto. Comparando vários depoimentos sobre os casamentos árabes pude verificar que os imigrantes preferiam procurar suas noivas entre os patrícios em outras localidades que não na própria cidade de residência. Em alguns 
Os casamentos árabes: a recriação de tradições entre imigrantes...

casos, isso significava trazer uma noiva da Jordânia, efetuando um casamento por procuração na cidade de origem da noiva (no exterior). Outras vezes, significava aderir a uma intermediação de mães e tias que faziam as tratativas para os noivados por meio de sua rede de interconhecimento entre as famílias imigrantes já residentes no sul do Brasil ou na palestina.

Explicavam-me que a expressão utilizada "casar entre os seus", era uma acusação ampla que encobria uma diversidade de situações e arranjos vistos como "nossos", dos árabes.7 De fato, me diziam que predominava um gosto por encontrar uma noiva ou um noivo que tinha sido "criado nos costumes". Casar "entre os seus" era também buscar noivos e noivas fora da sua própria cidade, e isso era algo mais relevante do que os "locais" supunham ou calculavam. Por outro lado, mesmo tendo "brasileiras" (não-imigrantes) na parentela, mostravam-me que uma pessoa, mãe ou tia casada com um imigrante, poderia ser classificada como "quase árabe" por agir de modo "mais árabe que as árabes". Também os filhos(as) nascidos no Brasil eram reclassificados como palestinos a partir de casamentos com outros(as) filhos(as) de imigrantes.

O problema seguinte era entender, então, como conseguiam tornar palpável esse mercado matrimonial? Como operavam essas classificações que os casamentos colocavam em movimento? Com certeza, para os "locais" isso não estava muito claro ou acessível e, para mim, restava saber como um sistema se tornava (ou não) sistemático.

Ingressando nas relações familiares dos entrevistados, centrei minhas atenções nas "falas nativas" e no drama das escolhas matrimoniais, especialmente para a geração de filhos de imigrantes nascidos no Brasil. Eles tinham que pensar quais as opções possíveis de trabalho, formação escolar e escolha de cônjuge, sem ter claro o que seria bem sucedido. ${ }^{8}$ Nesse tópico quero demonstrar como os casamentos contribuem para a definição de uma "família 
Denise Fagundes Jardim \& Roberta Peters

árabe", porque coloca em pauta um debate feito pelos próprios entrevistados sobre sua parentela. E a pergunta mais óbvia, como os filhos(as) de imigrantes são convencidos a escolher maridos e esposas entre "árabes"? Como são conduzidos a experimentar essa tradição como sua?

Há um intenso trabalho coletivo que revela os conflitos familiares e um amplo circuito de relações dos quais participam. Esse aspecto social é parte fundamental dessa "recriação de tradições". As festas são, a um só tempo, um fato mediador de confli-

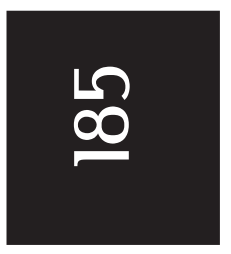
tos e um dinamizador de relações sociais entre as famílias de imigrantes. ${ }^{9}$ O convencimento implica em transformar uma pressão familiar entre gerações em uma disposição afetiva, sem produzir fraturas nas relações familiares.

Para se ter uma idéia de meu estranhamento inicial, queria compreender, por exemplo, como filhas de imigrantes, doutoras em psicologia ou outros cursos superiores (alguns cursados no exterior), ou filhos homens fazendo seleção para medicina, ou noivos que seriam primos tinham conhecido e escolhido seus cônjuges ou aceito uma intermediação que relatavam como uma escolha dos pais. Para tanto, ouvia seus relatos e observava em suas casas outros episódios sobre noivados e festas de casamentos que se desenrolavam. Todos os meus questionamentos me levavam a observar o que se passava entre as famílias e não só na família, mas com certeza era também uma observação sobre solidariedades e rivalidades nas famílias.

Outro aspecto que me chamava a atenção, e era parte de meu estranhamento, dizia respeito a essa primeira geração nascida no Brasil. Sobretudo, restava compreender as razões de, distintamente de outros imigrantes, os filhos nascidos no Brasil, em vez de esquecerem a origem, se esmerarem na conquista de um domínio pleno do código da sociedade de acolhida. Optavam por não "esquecer" as marcas do "turco", do "mascate que carrega sua maleta" e outros tantos signos de pobreza que carregam os 
Os casamentos árabes: a recriação de tradições entre imigrantes...

imigrantes. Eles, do contrário, se empenhavam em dominar tantos e variados códigos lingüísticos e investiam no auto-reconhecimento como palestinos. Traçavam novos significados nessa batalha contra imagens depreciativas. ${ }^{10}$

Neste artigo, nos referimos à recriação de tradições relativa a uma experiência imigratória. O fenômeno migratório é uma situação de ruptura que abarca uma situação especial com relação ao esquecimento e a lembrança. Entretanto, mesmo sem esse desenraizamento, não chegaríamos a uma "homogeneidade" das práticas sociais, nem para imigrantes árabes, nem para o vasto mundo árabe. Tomar as coisas desse modo seria um orientalismo ingênuo. Depois das pertinentes críticas de Edward Said (1990), é difícil aceitar a visão orientalista que unifica as diversas experiências do vasto mundo árabe a um tipo ideal, pois tal retórica tem convertido os árabes em seres "exóticos" e, muitas vezes, dotados de um sentido de humanidade quase exclusiva. Tanto melhor ir à campo sem ter muitas certezas do que seria a cultura árabe. Com vários parâmetros possíveis, poderia averiguar de que forma estão produzindo seus "modelos ideais" e sob que condições sociais. Como uma estudante de suas lições, me tornava atenta às suas considerações e classificações sobre um vasto modelo de "possíveis" da cultura árabe. Esses modelos eram trazidos de suas experiências diretas com as quais também tiveram que se familiarizar. Observando cerca de 10 famílias a partir de uma contabilidade que não coincide com suas residências, e sim com a indicação de "cabeças de família ou patriarcas", me utilizei da observação participante nas casas e na pequena cidade para entender as dinâmicas familiares.

Utilizo a perspectiva de Bourdieu (1997, p.139) ao tratar a família como "uma ficção bem fundamentada":

Para comprender como a familia passa de uma ficção nominal a um grupo real, cujos membros estão unidos por intensos laços afetivos, é necessário levar em conta todo o

Anos 90, Porto Alegre, v. 12, n. 21/22, p.173-225, jan./dez. 2005 
Denise Fagundes Jardim \& Roberta Peters

trabalho simbólico e prático que tem o costume de modificar a obrigação em amar em disposição amorosa e a dotar cada um de seus membros da familia de um "espírito de família" gerador de devoções, de generosidade, de solidariedades.

Os relatos de festas de casamento mostravam um jogo tenso das negociações entre pais e filhos em seus bastidores sobre quando ir ou não a uma festa de casamento. A citação de Bourdieu parece nos levar diretamente a um provérbio árabe que coletara naquela época:

"Ana dãd hái; Ana u hái a ãbn ami, u ana, hái u ãbn ámi dãd ál harib" - Eu contra meu irmão; eu e meu irmão contra meu primo, eu, meu irmão e meu primo contra o estranho. ${ }^{11}$

Mais do que um provérbio que expressa algo próprio dos laços familiares entre os árabes, ele aponta as tensões existentes nas relações familiares. Deveríamos compreender, então, como passamos de um comentário sobre o que se passa nas relações familiares, que poderia ter validade para qualquer realidade familiar ou étnica, para uma interpretação nativa. Essa leitura a tomaria como algo próprio e ilustrativo de uma família singular, própria de uma "família árabe".

O provérbio indica-nos uma pista e revela algo sobre o que atribuímos às noções de "família étnica". Em geral, alguns aspectos poderiam ser convertidos em exóticos, como próprios de um funcionamento familiar e que manteriam similaridades com outras "famílias étnicas". Em uma família "étnica" cada decisão envolve e mobiliza uma parentela mais ampla. Um parente está ligado a uma rede de obrigações e lealdade a outros. Nesse sentido, o que seria exclusivo de uma família italiana, alemã, cigana ou oriunda de Porto Rico emigrada é, enfim, algo exemplar de 
Os casamentos árabes: a recriação de tradições entre imigrantes...

uma experiência de grupo minoritário? As famílias étnicas parecem muito similares, especialmente quando nos interessamos em congelar suas características como próprias de uma "família extensa". Por si só, tal definição se contrapõe a algo igualmente idealizado como moderno e nuclear. Mas as confortáveis tipologias não nos deixam compreender as dinâmicas de decisões e tensões que percorrem um sistema familiar.

Prefiro compreender o provérbio acima exposto como um comentário que evidencia o jogo presente na parentela, nas relações sociais, e que refere seus conflitos e negociações simbólicas. Um simples comentário? Talvez não, sua força reside em dar indicações sobre um ideal de grupo e sobre como ele entende a força das relações familiares.

Com todas as precauções para não criar modelos unívocos para o "mundo árabe" em geral, quero fazer uma breve caracterização das tensões da vida familiar e de como elas cercam a boda.

Meus entrevistados enfatizavam a importância dos filhos em uma coletividade que dá muito destaque à linha de descendência paterna. Os indícios dessa importância se refletem na nominação que os filhos homens recebem. A linha de descendência paterna expressa parte desse mundo dos afetos com uma outra frase, "ninguém aprecia mais teu filho que teu próprio pai”. Reproduzindo o provérbio em árabe, o filho de imigrante mostrava a sonoridade da língua árabe e a circularidade contida nessa linha imaginária, um elo entre avô e neto, da mesma ordem daquela entre pai e filho. Ou seja, somente existe uma pessoa que ama mais a teu filho, aquele que te amou como filho. Essa expressão evidenciava os afetos distribuídos em uma linha imaginária, não só no lado paterno, mas entre homens. Mesmo assim, o provérbio lembra que junto com os afetos está posta uma obrigação e compromisso amoroso tecido por caminhos mais cotidianos, e a necessidade de corresponder a esse afeto.

Anos 90, Porto Alegre, v. 12, n. 21/22, p.173-225, jan./dez. 2005 
No caso das mulheres, depois de contrair matrimônio passam a adotar o sobrenome do marido ou todo o sobrenome do marido (sua linhagem), o que pode ser feito excluindo os sobrenomes da família de orientação. Em geral, quando casam, as mulheres poderão optar em retirar o sobrenome da mãe (no caso se for brasileira) ou de reordená-los, compondo-os na ordem brasileira. Em muitos casos, isso tem resultado em sobrenomes que evocam a origem árabe sem a necessidade de adotar inteiramente os sobrenomes do marido e excluir os de sua parentela de origem, já que de ambos os lados há ascendentes de origem árabe. Visto de fora, tudo soa como apenas árabe.

A nominação é o detalhe que nos leva a compreender como se expressam os interesses pela continuidade da família e pela explicitação de uma distinção étnica. Deste ponto de vista, explicita que essas famílias vivem entrelaçadas a outras famílias de origem árabe. Os nomes funcionam como uma apresentação inicial importante entre famílias, pois não se referem unicamente a laços de sangue, mas a aspectos morais que relacionam as qualidades morais do indivíduo a uma parentela mais ampla, conhecida e avalizada por outros imigrantes e comerciantes que atuam no sul do Brasil.

Para o provérbio que mencionamos, no qual se explicitam os laços entre pai e filho, existe um outro que expressa os vínculos das filhas e a família de orientação. As mulheres são vistas como a base do sucesso de uma família. Se um homem prospera, se uma família prospera, subentende-se e é dito que se deve ao fato de que a mulher (esposa e mãe) está "ombro a ombro" com seu esposo. Por outro lado, se um homem fica viúvo, na prática ele cai em uma espécie de esquecimento das relações familiares, torna-se queixoso quanto a seus pares o terem preterido, por exemplo, que "não o convidam para festas".

Uma frase explicita essa centralidade e a disposição social com relação às mulheres. Aparentemente, elas parecem "sair" de cena com o casamento. Dizem que "as mulheres voam com os 
Os casamentos árabes: a recriação de tradições entre imigrantes...

maridos". A frase é ampla e remete às várias situações do novo casal, e revelam também as disposições amorosas tecidas entre pais e as filhas. O que se pode esperar a partir do casamento de sua própria filha? Primeiro, que quase naturalmente ela irá morar com a parentela do esposo, assim como as noras virão morar na cidade ou na casa do seu filho, na sua própria casa. Essa mudança parece significar, em termos práticos, várias coisas: uma clara definição de herdeiros em potencial ou virtuais, e que os cuidados com os mais velhos acabam recaindo para os que ficam próximos dos pais etc. Note-se que para melhor realizar essa disposição amorosa em que potencialmente as filhas "voam", eles têm muito cuidado quanto ao lugar para onde é esse vôo. Assim como suas filhas são recebidas por outras famílias, eles devem ser muito receptivos com as noras que virão para sua família. Um bom casamento, um "casamento correto", será medido também pelo sucesso dessas solidariedades que tiveram que ser reorganizadas entre os demais parentes.

Minha leitura tende a mostrar que as mulheres não estão nas bordas de um sistema de parentesco, elas são centrais. Como dificilmente haverá uma partilha de herança, a manutenção de uma vida familiar tenderá a valorizar o sujeito como parte de uma totalidade necessária e para qual sempre poderá recorrer. Exceções existem, casamentos "errados" também; entretanto, aqui se vislumbram aspectos daquilo que é idealizado e exerce uma pressão sobre os sujeitos.

Tais disposições permitem uma reorganização e entrelaçamento de parentelas em que há um ritual de adesão a uma outra posição entre os pais do noivo por parte dessa noiva. Entenda-se aí parte das explicações do ritual da Hena, que veremos adiante, como um noivado que reúne a parentela dos noivos, momento em que as noivas são presenteadas pela família do futuro marido com jóias. Dizem ser esta uma expressão pública da importância dada à noiva e, diria eu, uma valorização prévia para bem receber a nova 
participante da família. Esse não é só o "preço da noiva", mas um ritual de expressão pública de como a nova família pretende tratála.

Diariamente, são as mulheres - mães e tias - que controlam e tramam considerações a respeito de seus filhos, com destaque ao que se passava na unidade doméstica e em relação aos casamentos. De modo muito pragmático, são elas que mantêm as trocas de cartas e fotos circulando nas redes de vizinhos no Chuí e entre parentes. Noticiam os nascimentos, colação de grau nas universidades, discorrem sobre os "frutos" e, potencialmente, medem as qualidades morais de outras famílias em detalhes cotidianos ou na avaliação das festas de noivado e casamento de outras famílias imigrantes ou residentes na Palestina - ou em outros países da América Latina. Fotos, cartas e mensagens por fax são os expedientes indispensáveis de uma comunicação, pois é difícil sair do local de trabalho apenas para visitar amigas e vizinhas de lojas em horas em que o movimento do comércio não seja intenso.

Nesse contexto, é possível discorrer sobre algumas das propostas de James Clifford (1997) sobre o fenômeno, especialmente quando se refere ao papel secundário das mulheres no fenômeno da diáspora. Clifford pergunta como incluir as mulheres nas histórias de diásporas. Por que elas não viajam? Para ele, elas viriam depois dos homens, depois de um período de instalação. Todavia, podemos conhecer, por meio dessa experiência de diáspora palestina, que a viagem tem outro tempo e significados para as mulheres. Creio que há um outro circuito de viagens que é a possibilidade de manter a parentela em deslocamentos de longo prazo e de imensa relevância à diáspora. São elas que organizam o circuito e os itinerários de viagem da parentela; ao traçar casamentos entre conhecidos e parentes em cidades e países distantes, elas colocam no horizonte familiar a possibilidade de novos itinerários. Mesmo que elas não sejam as "pioneiras", mesmo que elas tenham chegado depois e por intermédio dos maridos, essas

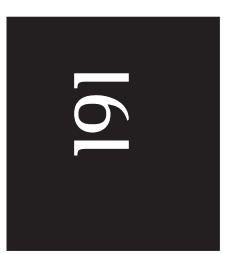


Os casamentos árabes: a recriação de tradições entre imigrantes...

mulheres se encontram em um momento fundamental da constituição de uma nova unidade doméstica. Não podemos deixar de ressaltar que essa nova unidade é também uma unidade de trabalho familiar que viabiliza a vida do imigrante. São elas que mantêm a parentela com seus vínculos familiares extralocais, traçando planos a longo prazo, planejando novos encontros da parentela. Enquanto os homens imigrantes falam de sua vinda para o Brasil, de sua viagem para peregrinar a Meca, as mulheres falam dos vários e constantes desenraizamentos atualizados nos noivados e vislumbram bodas possíveis entre parentes que recebem e enviam notícias sobre potenciais noivas.

Os filhos de imigrantes estão em contínuo aprendizado sobre o "mundo árabe" e, muitas vezes, desvendando pela primeira vez o mundo social dos pais e de suas origens. Estão "aprendendo" os códigos e procurando modelos aceitáveis para si e para seus pais com respeito ao que poderiam vislumbrar para o futuro. Isso também inclui uma parentela mais ampla.

Quero descrever algo dessa dinâmica familiar e os conflitos que a atravessam. Sem esse rico contexto de tensões e conflitos, não é possível entender totalmente o apelo que as "bodas" despertam para os filhos de imigrantes. Ficaríamos com a idéia de um funcionamento "próprio" (a partir de minha própria ilustração dos provérbios), sem perceber que as tensões desse sistema familiar e dessas disposições amorosas encontram nos casamentos uma mediação social importante das relações familiares.

Minha observação no Chuí entre as famílias de imigrantes indicou que as festas são um momento de resolução de conflitos e incertezas. Traçar um casamento entre os seus requer uma disposição anterior dos filhos em participar e aceitar esse arranjo como algo plausível. Valeria conhecer um pouco mais das tensões dos "bastidores" da festa. Mesmo que o circuito de festas seja muito apreciado, ele acaba movendo decisões. Apresentar-se ou não nesse palco público de desposáveis? Esse é o momento em que

Anos 90, Porto Alegre, v. 12, n. 21/22, p.173-225, jan./dez. 2005 
Denise Fagundes Jardim \& Roberta Peters

os conflitos entre parentes transparecem. Deve-se lembrar que no Chuí, diziam os jovens, não há namoro, "só escondido", e que o ingresso nesse circuito é entendido, sobretudo, como uma atitude pública de disposição para noivado. O provérbio nos revela sobre a dinâmica das decisões na parentela, algo singular, mas que não se revela inteiramente no provérbio. Refiro-me à solidariedade na mesma geração.

Vamos voltar ao primeiro provérbio: "Ana dãd hái; Ana u hái a ãbn ami, u ana, hái u ãbn ámi dãd ál harib" - "eu contra meu irmão, eu e meu irmão contra meu primo, eu, meu irmão e meu primo contra o estranho". O provérbio pode ser compreendido em múltiplos sentidos, mas nos permite uma melhor explicitação de seu sentido por meio da observação do trabalho de campo. $\mathrm{O}$ provérbio refere-se a uma unidade que se constitui a partir de conflitos com um estranho. Ele tem a riqueza de mostrar o "estranhamento" entre os membros da família. Assim, se não é uma explicação do funcionamento de uma família árabe, porque poderia estar em qualquer família, o provérbio necessita de sua base, ou seja, mostrar como são tecidas as solidariedades na mesma geração em uma família, no caso, árabe. Não se trata de revelar um funcionamento da família árabe, e sim de evidenciar uma dinâmica em que algumas solidariedades são vivenciadas e retomadas pelos sujeitos envolvidos como próprias de "sua família".

Mesmo que o circuito de festas seja muito apreciado, ele acaba movendo decisões. Apresentar-se ou não nesse palco público de desposáveis? Esse é o momento em que os conflitos entre parentes transparecem. Deve-se lembrar que no Chuí, diziam os jovens, não há namoro, "só escondido", e que o ingresso nesse circuito é entendido, sobretudo, como uma atitude pública de disposição para noivado. O provérbio coincide com a observação das relações entre irmãos que observara em campo. Muitos de seus conflitos reproduzem a tentativa de recriar entre irmãos uma hierarquia tal qual aquela conhecida na relação de autoridade entre pais e filhos, só 
Os casamentos árabes: a recriação de tradições entre imigrantes...

que transposta a critérios de idade ou sexo, como se as relações entre irmãos (entre eles) devessem seguir alguma ordem de ascendência de um sobre o outro irmão, uma disputa sobre autoridades. Isso se traduz em tensão, mais do que real obediência. Dificilmente um irmão irá denunciar os erros de um irmão, sob o risco de viver a possibilidade de ter "a volta". Um "namoro escondido" dos pais, por exemplo, pode não ser denunciado pelo irmão, mas pode virar motivo de barganha em vários sentidos. Os conflitos entre irmãos se revelam na tentativa de exercício de controle dos homens sobre as atitudes e a pureza das irmãs, o casamento de uma árabe valoriza a virgindade da noiva, como ideal de pureza moral da família. Ou disputa-se o controle dos irmãos por ordem etária e controlando as rotinas e a divisão do trabalho devida pelos mais novos. Alguns irmãos podem assumir, com o passar dos anos, a função de conselheiros entre os irmãos, conquistar respeito, ser uma voz a ser escutada na tomada de decisões, ou mesmo se tornar um porto seguro para situações complexas da vida de seus irmãos. Entretanto, conquistar isso pode significar um longo caminho de tensões e uma eventual desautorização e escárnio por estarem tentando fazer algo ilegítimo e próprio somente para os pais.

Dizem meus entrevistados no Chuí que uma nova família deveria, como ideal, ter ao menos quatro filhos. Essa geração de imigrantes tem muitos filhos, e estes, muitos primos. As afinidades e conflitos entre irmãos são traduzidos nos atos corriqueiros de tentar conduzir moralmente outro irmão ou irmã. Em contraposição, as relações entre primos são vistas como de alianças em potencial. Ou seja, para fazer frente a um irmão, chama-se a solidariedade e a vOz do primo a seu favor (evidentemente, um escolhido entre os primos). Eles serão seus aliados nessa geração, e que irão reforçar sua própria posição. Assim, na parentela se reproduzem relações de alianças e rivalidades e evidenciam-se solidariedades. 
Os próprios entrevistados lembram dessa extrema afinidade entre primos, uma aliança e compreensão mútua, como me disseram, "quase telepática". Por vezes, uma compreensão mútua melhor com a prima do que com sua própria irmã. No Chuí, dizemme que tal "telepatia" e afinidade tornam inviáveis alguns casamentos entre primos, pois, na prática, eles aprenderam a se ver como irmãos. A partir daí, me revelam sobre as sugestões e tentativas de casamentos ofertadas por tios e tias, dos quais já declinaram.

A relação entre primos reforça alianças em uma mesma geração. Entende-se que dessa solidariedade surja quase uma promessa, uma disposição em casar seus filhos no futuro, como uma maneira de manter esses vínculos. Todavia, nem tudo se concretiza, as redes de parentes são mais amplas e permitem sempre uma inclusão de novos membros. Quando observamos as famílias que participam das festas e a quantidade de parentes possíveis e desposáveis, percebemos a força de incorporação e circulação de membros entre famílias de origem árabe. O circuito de festa contribui para que as "famílias" se mantenham conectadas e plenas de novos parentes e potenciais primos.

As relações entre pais e filhos seguem uma particular hierarquia. A expressão da vontade de um filho poderá ser intermediada pela mãe para chegar ao conhecimento do pai. De forma indireta, o filho saberá o resultado, a decisão, e a opinião de seu pai sobre um assunto de seu interesse. Até que se torne um adulto e seja visto como um interlocutor, as relações entre parentes são cheias de intermediários. Embora isso não seja uma regra, traduz uma relação de respeito mais do que de "medo". A concordância paterna ou materna é algo a ser conquistado. As relações familiares nos demonstram um intenso trabalho de conquista de afetos, de respeito dos pais por parte dos filhos. Tais disposições se transpõem ao terreno das decisões sobre casamentos e sobre a participação nesse mercado matrimonial. 
Os casamentos árabes: a recriação de tradições entre imigrantes...

Nas situações que observei, parte das dinâmicas entre os filhos girava em torno da previsibilidade da reação dos pais, se algo agradaria ou não. Não se trata de conflitos graves, mas de tensões criadas e que atrapalham a comunicação direta entre pais e filhos, ou seja, entre gerações, e que são mediadas por outras solidariedades (de primos ou tios). Um tio paterno ou tia paterna pode se tornar um bom mediador de uma geração para declarar vontades a outra, ou seja, mediações por meio de pessoas que os cercavam, indiretamente, "sondando" ou "averiguando" a aceitação prévia de uma decisão, que em geral envolvia mudança de cidade para estudar e a definição de universidades onde estudar (particular ou pública). Me diziam, em termos práticos, a vantagem de ter como sogro o seu próprio tio, como parte da explicação sobre os benefícios de casar com um primo. "Teu sogro será teu aliado em caso de briga do casal", ele será um mediador. Mais do que explicar a vantagem do arranjo matrimonial entre primos, revela-nos mais uma face dessas solidariedades e princípios de hierarquia presentes na parentela.

Em geral, os estudos sobre famílias árabes referem a existência de muitos primos e, ao final das contas, a constatação "nativa" de que todos os árabes são potenciais primos. Essa observação tem permeado trabalhos sobre imigrantes de origem árabe, entendida como algo relacionado à sua definição como uma família extensa. Contudo, a solidariedade entre primos deveria ser vista como algo socialmente produzido em suas dinâmicas internas, pois está conectada às noções nativas de definição da família árabe. Essa solidariedade entre gerações é mediadora de muitos dos conflitos presentes em uma unidade doméstica entre pais e filhos. Os primos e sua participação nas relações entre parentelas mostram-nos um sistema familiar mais amplo das formas de solucionar conflitos domésticos. Interferem como testemunhas do que ocorre nas unidades domésticas alheias, ou intercedem por alguém conectado à parentela, ou que exerceria influência sobre o pai ou os filhos.

Anos 90, Porto Alegre, v. 12, n. 21/22, p.173-225, jan./dez. 2005 
Essas solidariedades reaparecem no momento das bodas. ${ }^{12}$ Nesse caso, as bodas exteriorizam os conflitos e solidariedades. É o momento em que devem decidir se participarão ou não como convidados, declarando sua existência a esse mercado matrimonial. Nas festas de casamento, por exemplo, essas solidariedades são reproduzidas no salão, quando bailam como os "seus", marcam grupos de idade e espaços masculinos e femininos, fazem a festa não somente entre homens solteiros e mulheres solteiras, primos e primas. Em um mesmo sentido, a decisão de ir à festa de casamen-

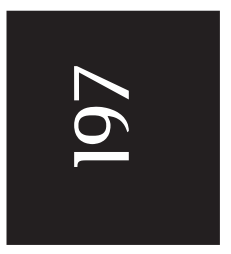
to nunca será individual ou uma adesão à proposta dos pais, e sem uma extensa campanha e pressão entre os primos e amigos para que assistam juntos ao evento. Em outras palavras, ao assistir ao casamento emitem uma mensagem bastante ambígua, de que irão à boda para corresponder às expectativas de seus primos e a essa solidariedade, e enfatizam que não estão em um casamento para corresponder a uma expectativa dos pais que dela participam, e sim a um chamado dos primos.

Voltemos a uma pergunta-chave. Como são possíveis os casamentos entre parentes (primos) e arranjos pré-nupciais? Como os filhos adotam as propostas oriundas de seus pais ou tios, como algo aceitável ou bom? Em primeiro lugar, a resposta é complexa e muito relativa, mas em parte deve ser encontrada nos mediadores dos conflitos na parentela, ou seja, no papel que têm os "primos" em estabelecer uma solidariedade generacional, válida e conhecida de seus pais e tios. Para compreender a aceitação de uma "boda" entre os "seus", devemos ter presente que os méritos não são unicamente resultado do talento de uma família, ou de suas mães ou tias que fazem o papel de casamenteiras. Há um circuito de "casamentos" muito comentado entre os patrícios a ser conhecido, comentado em sua grandiosidade e intensidade da celebração, instigante aos olhos de "outros" e de "locais".

A primeira atitude decisiva para um casamento entre primos, ou um casamento arranjado entre famílias de imigrantes, é 
Os casamentos árabes: a recriação de tradições entre imigrantes...

o próprio comparecimento às festas junto a seus primos e irmãos. O circuito de casamentos os aproxima e parece ser produzido por motivações similares àquelas conhecidas por tios e pais. Ir a uma festa é um ato de solidariedade aos seus primos e, dizem, não necessariamente estariam cedendo às vontades dos pais. A solidariedade da mesma geração se afirma nas festas de casamento, que também permitirão fazer a aproximação entre seus filhos. Resulta que estão envolvidos no interesse e na crença comum dos benefícios da solidariedade entre primos.

Um casamento entre irmãos de uma família com irmãs de outra, além de produzir um cruzamento entre parentelas, pode, mais adiante, deixar revelar aos filhos uma relação anterior entre os progenitores dos noivos. Enfim, a posteriori se poderá saber tratar-se de um casamento entre primos. Mesmo que esses fatos são fossem plenamente conhecidos pelos noivos no momento da decisão pelo casamento, retrospectivamente, este pode ser publicizado como um casamento "entre primos". Isso pode ser apenas uma casualidade, mas saliento que era a casualidade que todos estavam esperando, ou ao menos, construindo coletivamente.

Como veremos, as festas de casamento são um momento de afirmação de cumplicidades que não tem uma única intenção de traçar casamentos, mas algo mais importante, e definidor os casamentos entrecruzados, que é a participação em um circuito inclusivo, em que são conhecidos aqueles que podem casar ou que são vistos como disponíveis.

\section{As festas de casamento como expressão de um ethos}

O trabalho de campo que deu suporte para este ensaio foi nos anos de 2003 e 2004, com imigrantes palestinos e seus filhos nascidos no Brasil, residentes em Porto Alegre e Canoas. ${ }^{13}$ Nessas

cidades, há uma grande concentração de famílias palestinas, entre 
Denise Fagundes Jardim \& Roberta Peters

as quais as famílias Baja e Bakri configuram-se como as mais extensas e tradicionais no estado do Rio Grande do Sul.

Durante a pesquisa, muito me chamou atenção o fato de esses migrantes casarem com seus primos de primeiro grau, geralmente da linhagem paterna. Tal arranjo é tido como próprio da tradição e dos costumes árabes, por isso a primeira máxima que ouvia nas entrevistas era sabes que os árabes casam com primos? Ao investigar a recorrência e o significado desse padrão, fui gradativamente percebendo a importância do ritual da hena (festa que

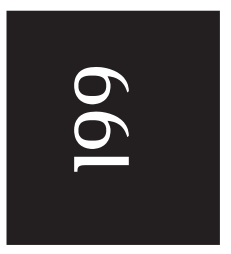
antecede o casamento e serve para dar sorte ao casal) e da festa de casamento como eventos vividos como centrais na vida dos meus entrevistados.

Sabemos que o ritual da "hena" tem muitos significados possíveis. É uma apresentação pública dos noivos para seus parentes. Muitas vezes, em uma festa que reúne somente mulheres casadas e os noivos. É a ocasião em que elas (mulheres casadas) desejam boa sorte ao casal. Para marcar esse encontro, o casal é rodeado com dança e música por suas parentes, e a palma da mão da noiva ou dos noivos é pintada com a tinta hena. Em Canoas, a mistura é preparada alguns dias antes do ritual, à base de chá preto e fermento de pão para fixá-la na pele. É feito um bordado ou uma simples marca (um coração ou traço) para, como dizem no Chuí, desejar boa sorte. Tal marcação na mão permanecerá por cerca de 15 dias até a tinta desaparecer.

Pode-se dizer que o ritual antecede a entrada da noiva no mundo das mulheres casadas, que o casamento consagrará. Mas há um sentido de separação e agregação da noiva em um novo grupo (de gênero), também que a noiva detém um status diferenciado e superior ao das mulheres solteiras.

Em Canoas, as famílias indicaram que a festa também é vivida como uma despedida de solteira, e relatam que na Palestina a hena é um evento realizado separadamente, para homens e mulheres. Explicam que isso não ocorre aqui porque consideram o 
Os casamentos árabes: a recriação de tradições entre imigrantes...

país mais liberal. Entretanto, mencionam o quanto é diferenciado o significado do ritual nos dois contextos. A moça que nasceu na Palestina e vai casar em outra localidade perceberia a festa como uma mudança não só de status, mas também uma despedida da família e dos amigos. Isto porque o casamento pressupõe um deslocamento, um novo lugar de moradia. Assim, não é qualquer música árabe que sonoriza o momento de pintura das mãos durante o ritual, mas sim uma melodia cuja letra diz para a mãe arrumar as malas da filha. Me traduzem a música. Nela, a noiva pede que sua mãe espere um tempo, demore um pouco mais, para que ela possa se despedir de todos. Esse tempo referido na música é o intervalo de alguns dias entre a celebração da hena e a cerimônia muçulmana de casamento.

Em alguns casos, como no Chuí, a vida de casada significa uma mudança de cidade ou a moradia temporária na casa dos sogros. Onde poderia haver somente uma festa de casamento, também há uma festa de despedida realizada entre os parentes imediatamente envolvidos na vida do casal e nas futuras decisões. No Chuí, o ritual da Hena é a ocasião em que as mulheres vestem seus trajes bordados, confeccionados na palestina, trazidos como presentes de viagem, e podem usar as jóias que receberam como presente do marido no seu próprio ritual da hena. É interessante notar que em alguns dos rituais observados em Canoas, a noiva não usa trajes típicos; ele é somente utilizado pelas mulheres casadas. As jóias lembram a importância atribuída à noiva pela família do noivo. Calcula-se a importância da noiva de acordo com o volume de jóias recebidas por ela; muitas vezes os parentes que vêm da Palestina para o casamento trazem as jóias de lá. São presentes e, em termos técnicos, os antropólogos conhecem a prática como "o preço da noiva", mas não se deve reduzir a questões práticas os significados que isso põe em circulação na vida do grupo.

A hena tem inúmeras variações e interpretações possíveis; pode ser interpretada como um noivado, um ingresso no mundo 
das mulheres casadas, uma exposição da importância dessa noiva para a parentela do marido - traduzida pela ostentação das jóias por ela recebidas. Mesmo estabelecendo comparações, evidenciamos a singularidade e a diversidade das festas.

Nosso trabalho de campo em Canoas mostra que os casamentos que fogem ao padrão desejado pelos pais também são momentos especiais para compreender a especificidade da família árabe, na medida em que ocorre uma série de negociações de significados partilhados. Além de ter ido pessoalmente a um casamento, pude assistir a filmes de outras festas, comentados pelos entrevistados nas situações de encontro etnográfico. ${ }^{14}$

Assim, a ritualização da festa varia conforme o significado do casamento na família e entre famílias, pois pode remeter ou não a um modelo legitimado e valorizado pela comunidade. Dificilmente, posso tomar uma única festa como exemplar de um padrão de ritual, na medida em que há uma abertura ao contexto e uma negociação de sentido. Contudo, a descrição que farei neste ensaio permite situar o leitor no contexto de uma festa, de uma forma possível de ritualizar o casamento entre os árabes. $\mathrm{O}$ que interessa na análise do ritual é entender como ele torna compreensível a experiência comum, ou seja, como ele dramatiza essa experiência no que toca aos arranjos matrimoniais e à própria trajetória de migrante dos atores envolvidos. Assim, o casamento é uma leitura do grupo sobre a experiência deles próprios. Ao descrever uma festa não estou tomando-a como modelar, mas exemplificando uma leitura dramatizada.

No dia vinte e sete de novembro de 2004, às 20 horas, no CTG (Centro de Tradições Gaúchas) Rancho da Saudade em Cachoeirinha, no Estado do Rio Grande do Sul, casaram-se Amir Baja e Michele Silveira. Ele, filho de comerciante palestino e mãe uruguaia e ela, filha de pais brasileiros, oficializaram o matrimônio na religião muçulmana perante um público de aproximadamente 600 pessoas, entre elas palestinos e seus descendentes e outros brasileiros sem origem árabe. 
Os casamentos árabes: a recriação de tradições entre imigrantes...

Com o objetivo de registrá-lo para minha etnografia, compareci ao evento com o convite concedido pela família Baja. Fui ao casamento mesmo sem ter entrevistado o casal. A oportunidade foi decorrente de uma entrevista realizada semanas antes com uma tia do noivo, uma senhora de meia-idade que concordou em falar sobre as festas de casamento dos filhos e sobre a sua trajetória como migrante. Nesse encontro, ela falou-me que o sobrinho estaria se casando. Recebi um convite dela sem ao menos conhecer os noivos. Para eles, isso não tem o menor problema, pois o casamento é um evento público que se torna grandioso também pelo número de convidados que recebe.

$\mathrm{Na}$ entrada do Centro de Tradições Gaúchas, local escolhido para celebrar o casamento, os pais dos noivos recepcionavam todos que chegavam. O galpão rústico onde ocorreu a festa foi ornamentado como se fosse um salão de festas de clube, onde tradicionalmente ocorrem festas de casamento tanto de brasileiros como de palestinos. $\mathrm{Na}$ entrada, tules e panos brancos formavam corredores por onde passávamos; flores e fotos do casal associavam-se à decoração com tecidos que parecia reproduzir uma tenda. Já no salão, um altar foi montado para a realização da cerimônia, perto dele havia um telão que transmitia o evento e uma banda de músicos com instrumentos árabes. No momento de chegada dos convidados, um DJ sonorizava o ambiente com músicas árabes, pois o cantor e a banda ainda não tinham se apresentado.

No horário que cheguei, o salão estava praticamente lotado. Com a ajuda de uma pessoa do cerimonial consegui me instalar no mezanino, ao lado do altar. Nas mesas havia flores e pequenas lembranças para os convidados levarem para casa. Logo, chegou o Cheh (autoridade religiosa que celebra o casamento) usando um terno com duas pequenas bandeiras na lapela, uma da palestina e a outra do Brasil. Na cabeça, usava o hata (lenço usado pelos homens muçulmanos) e na mão trazia o Corão (livro sagrado muçulmano). Como estava acompanhado de muitos outros homens e os 
pais dos noivos estavam se organizando para entrar sobre o tapete vermelho que levava ao altar, resolvi me deslocar para o centro do salão para fotografar a cerimônia.

Em volta do centro do salão distribuíam-se as mesas para os convidados, uma grande mesa com frutas, outra com doces, outra com café em bules árabes e na ponta do salão havia uma mesa comprida onde sentariam os noivos e seus familiares. Os primeiros a entrar foram o noivo e sua mãe, depois a mãe da noiva acompanhada do pai do noivo. Posteriormente, entraram no salão os padrinhos. Nesse momento o cantor começara sua apresentação do repertório árabe. As letras das músicas geralmente falam sobre casamento.

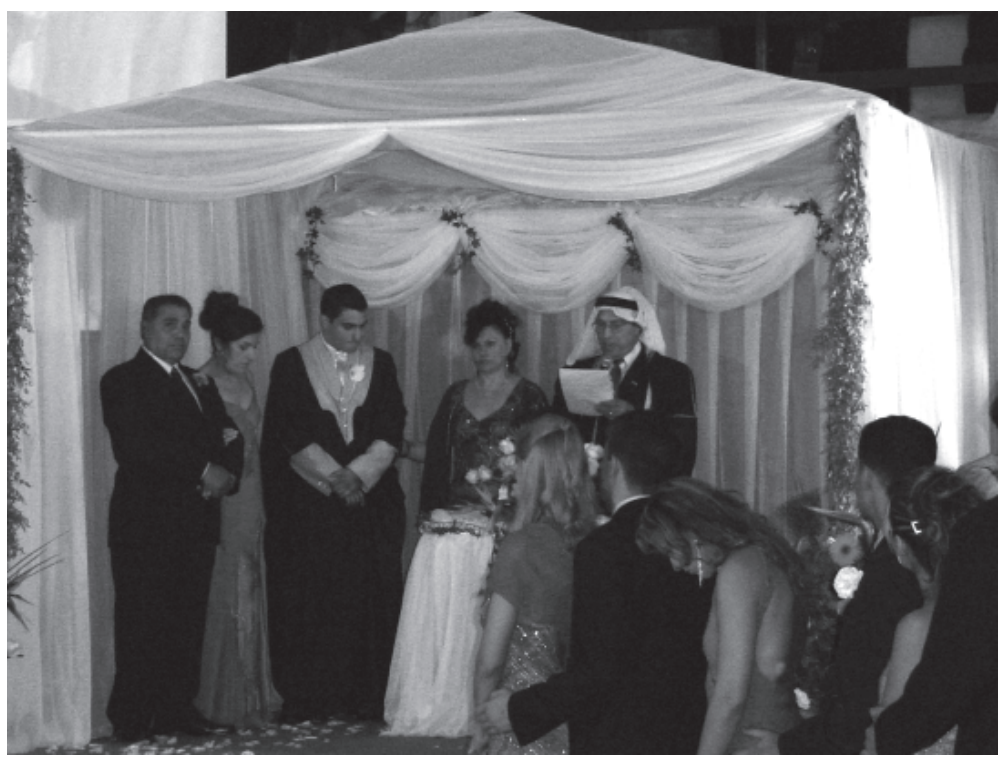

Figura 1 - Na tenda montada para a realização da cerimônia, o Cheh anuncia a entrada da noiva.

A platéia participa dessa abertura do ritual com muitos aplausos. Antes da entrada da noiva, o Cheh explicou aos "irmãos

Anos 90, Porto Alegre, v. 12, n. 21/22, p.173-225, jan./dez. 2005 
Os casamentos árabes: a recriação de tradições entre imigrantes...

brasileiros e palestinos" que a cerimônia estaria começando e que seria traduzida para o português, já que a noiva é brasileira. Por fim, entra a noiva acompanhada de seu pai, usando um vestido branco com a parte do véu cobrindo a parte inferior dos olhos, tal como uma árabe muçulmana. A música de entrada não era árabe, mas sim uma música clássica. Na metade do percurso, antes de subir ao altar, Michele retira o véu do rosto, todos aplaudem e dáse início à cerimônia oficial de casamento muçulmano.

Em geral, as festas de casamento assistidas variam com relação à ordem do cerimonial, a quantidade de discursos proferidos durante o evento, a quantidade de noivos casando numa mesma cerimônia e também ao número de famílias convidadas.

Freqüentemente, os casamentos a que assisti em vídeo ocorreram entre primos paralelos. Como esses eventos são considerados próprios da cultura e dos costumes, isto é, são vividos como primordiais pelos entrevistados, são também os primeiros a serem mostrados à pesquisadora. As fitas a que tive acesso são de grandes festas onde casam dois ou três noivos, primos, muitas vezes, dos mesmos tios. No entanto, essa dinâmica de reciprocidade onde um sujeito pode casar dois ou mais filhos com os filhos de seu irmão só pode ocorrer em famílias extensas, devido à quantidade de primos disponíveis.

Parto da pressuposição que numa situação social ritualizada representa-se ou se interpretam as inter-relações humanas. Nesses momentos, as pessoas experenciam e reelaboram questões sociais pautadas pelo grupo. A mensagem do drama reinventa a sua própria estrutura. O desafio para o cientista social é compreender o que essa experiência humana está comunicando, posto que o ritual é uma forma de representar a realidade de forma diferenciada.

Penso o ritual não como algo definido de antemão pelo antropólogo, mas como um evento especial em termos nativos. Tal como propõe Tambiah (1985), sugiro que o ritual é uma ação social que se realiza no contexto das visões de mundo partilhadas.

Anos 90, Porto Alegre, v. 12, n. 21/22, p.173-225, jan./dez. 2005 
Denise Fagundes Jardim \& Roberta Peters

Assim, busco perceber como as características do ritual do casamento estariam relacionadas com o contexto maior das normas sociais, das convenções e das práticas culturais.

Dessa forma, gostaria de me deter em duas performances específicas que considero centrais para a análise antropológica dessa festa descrita, a da noiva e a do Cheh. Nesta festa, este foi o senhor Sales Baja que, recentemente, recebeu a autorização da religião islâmica para celebrar casamentos. A entrada da noiva foi o grande momento da festa. A moça, cuja idade parece beirar os 25 anos, apresenta o estereótipo atribuído aos árabes: cabelos escuros, nariz saliente e olhos castanhos. O casamento para ela, talvez mais do que para uma mulher descendente de palestinos, marcou uma passagem. Além do status de casada - como sugere Turner (1974), os ritos marcam a passagem do indivíduo de uma condição social para ocupar outra posição na estrutura social -, o enlace matrimonial significou para ela o reconhecimento de que estaria se tornando "árabe" ao casar com um filho de palestino.

Logo, além da aquisição de um novo status devemos evidenciar que cenicamente o ritual sobrepõe dois registros, uma nova posição adquirida nas relações familiares - algo que poderia ser comum aos rituais de casamento - e uma separação da família de origem e uma nova morada com o noivo, que o ritual explicita. Todavia, o ritual explicita uma nova condição e reconhecimento de ingresso em valores morais que dizem respeito à origem árabe $\mathrm{e}$ que colocam em evidência o lugar e a posição de uma esposa no conjunto desses valores singulares. Portanto, o ritual é, de certa maneira, pedagógico. Nesse caso, toma-se o tempo para explicitar e ensinar.

Mas como isso se efetiva de forma performática no ritual? O próprio casamento é também uma conversão para a religião muçulmana explicada para a platéia passo a passo. $\mathrm{O}$ fato de a noiva ter entrado usando um véu no rosto remete a uma prática recorrente entre as mulheres muçulmanas que, em público, ao menos 
Os casamentos árabes: a recriação de tradições entre imigrantes...

nesse contexto, simboliza o cuidado com sua identidade e com o zelo à honra da família. ${ }^{15}$ Apesar de o objetivo não ser discutir a origem do uso do véu entre as mulheres muçulmanas, é interessante atentar para a bricolagem de símbolos que o ritual promove.

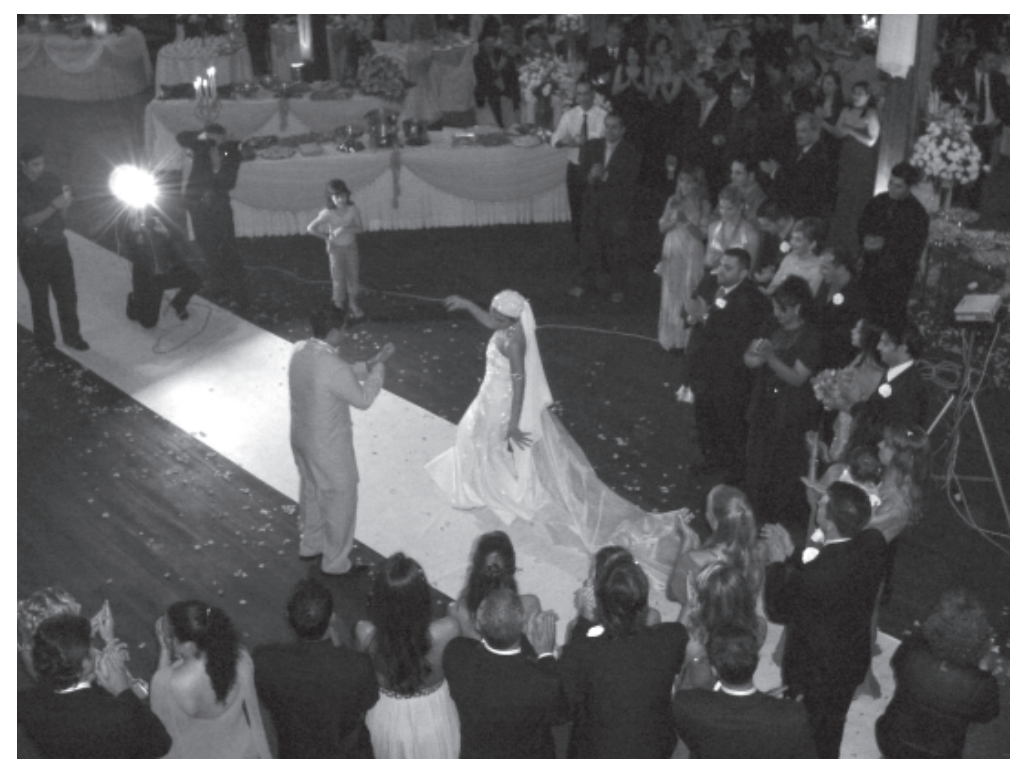

Figura 2 - Após o termino da cerimônia, o casal dança enquanto os familiares formam um círculo à volta deles.

$\mathrm{Na}$ cerimônia, ela precisou repetir as palavras sagradas lidas do Alcorão reconhecendo Allah como o Senhor do universo, o Clemente, Misericordioso. Oficialmente, ela se tornou muçulmana ao casar com um árabe e jurar a palavra.

A cerimônia de casamento marcou um ritual da passagem da noiva, simbolizando a morte para sua cultura e o renascimento em outra, a do marido. Pelos seus atos performáticos a noiva estava sendo avaliada pelo público quanto à sua competência em se tor- 
Denise Fagundes Jardim \& Roberta Peters

nar uma "boa" esposa. Essa concepção de passagem para uma outra "cultura", está relacionada com a visão de mundo do grupo no qual a mulher, quando casa, migra para a parentela do marido. Durante a cerimônia, Michele foi chamada de Amira (feminino de Amir, seu marido) como se estivesse sendo rebatizada perante a comunidade palestina como um novo membro do grupo.

Os atos performáticos da noiva nesse momento de limiaridade comunicam a nova posição que ela terá na organização social do grupo. Este legitima essa nova condição, participando do ritual e o vivendo como tradicional e primordial nas suas vidas. O ritual apresenta os aspectos "pedagógicos", servindo a uma iniciação a aspectos da tradição.

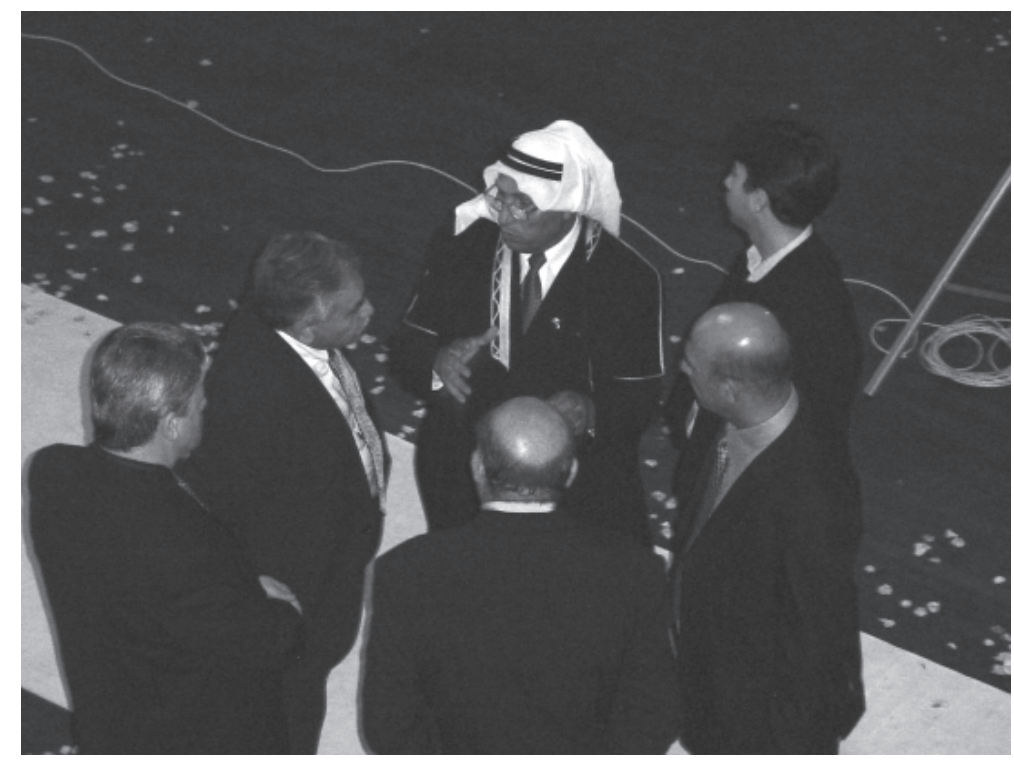

Figura 3 - Sales Baja (usando um lenço islâmico na cabeça) com alguns patrícios.

O discurso do Sr. Sales Baja é sempre de interlocução entre sua condição de migrante. Palestino vivendo em localidade

Anos 90, Porto Alegre, v. 12, n. 21/22, p.173-225, jan./dez. 2005 
Os casamentos árabes: a recriação de tradições entre imigrantes...

brasileira. Há alguns anos, recebeu a autorização para celebrar casamento dentro da doutrina islâmica.

Atualmente, entre a comunidade palestina residente em Porto Alegre e região metropolitana, Sales Baja é o mais autorizado a falar de religião. Há ainda um centro islâmico em Porto Alegre e um clube em que outros imigrantes conduzem rituais religiosos. Coincidentemente, a família Baja no Estado do Rio Grande do Sul é uma das mais extensas e tradicionais e, nessa festa, casou seu sobrinho (filho de seu irmão, também nascido na palestina). Em seus discursos, geralmente é o único na cerimônia que discursa ao microfone para todos os convidados, sempre fazendo referência à condição de imigrante dos patriarcas da família Baja e da acolhida afetuosa que receberam no Brasil.

$\mathrm{O}$ fato de as festas congregarem os "irmãos brasileiros e palestinos" revela questões da relação política entre estrangeiros e "locais". Como sugere Kertzer (2001), os ritos são fundamentais para o processo de associações de indivíduos com entidades simbólicas como partidos, ou neste caso, "nações". Também desempenham uma função organizacional importante ao diferenciar o "grupo-de-fora" do "grupo-de-dentro". A dramatização da experiência da migração contribui para reforçar um sentimento de solidariedade étnica, na medida em que reforça uma condição social comum.

No entanto, apesar de haver uma certa recorrência e coerência no discurso nas festas, eles parecem improvisados e situados no contexto da cerimônia. Para Tambiah (1985) essa abertura com relação ao contexto é o grande paradoxo do ritual. Ao mesmo tempo em que apresenta uma forma prescrita, ordenada e aparentemente invariável, uma performance nunca vai ocorrer de uma mesma maneira. Nessa abertura em relação ao contexto está a flexibilidade do evento e a sua conseqüente imprevisibilidade.

Assim, o casamento é um momento especial para os mais velhos falarem sobre sua origem, trajetória, religião e sobre a tradição. Imprime laços de afetividade e solidariedade por ser uma

Anos 90, Porto Alegre, v. 12, n. 21/22, p.173-225, jan./dez. 2005 
experiência comum a muitos convidados da festa, e ratificam a importância dessa trajetória para as gerações mais novas, que estão negociando suas possibilidades de acordo ou não com o que identificam ser a "tradição".

As festas também são momentos importantes de sociabilidade. Ao mesmo tempo em que reúnem os patrícios de diversas regiões, estabelecem relações com a localidade na qual estão inseridos. É comum que as cerimônias religiosas de casamento reúnam políticos locais, embaixadores da palestina, convidados especial-

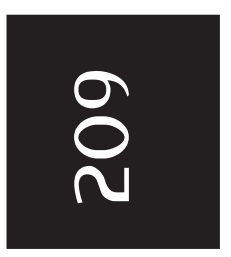
mente para a festa e comerciantes locais. Lembramos que os migrantes palestinos dedicam-se prioritariamente a práticas comerciais, e as festas explicitam suas relações locais. Além disso, a grandiosidade da festa coloca a família em um circuito de relações de famílias palestinas onde o poder do ritual está em publicizar o quão bem sucedida foi sua experiência de imigração.

Nas festas assistidas em vídeo, é recorrente haver um orador ou um representante da família fazendo um discurso em português em homenagem à família e agradecendo a presença. Em uma filmagem de um casamento na família Bakri, o orador dizia que essa família é muito grandiosa e que era um orgulho para o mundo árabe. A noite era de muita importância, pois pela grandiosidade da festa tem-se uma idéia da grandiosidade do mundo árabe e, também, de que o povo palestino é um povo livre e soberano. Assim, fica claro o caráter público da festa, o que também expressa uma relação política com a localidade. Ao mesmo tempo em que o evento promove a sociabilidade entre as famílias árabes, expressa uma interface com a sociedade local.

Em uma das festas da família Baja, alguns pontos sinalizaram o reconhecimento de que, nos termos nativos, se tratava de um casamento misto. E, portanto, há uma forte explicitação, algo pedagógico, do que deveria ser conhecido como um evento tradicional árabe e algo das tradições árabes. $\mathrm{O}$ casamento entre um descendente de palestino e uma moça de família brasileira demarca o novo status atribuído a ela durante a cerimônia.

Anos 90, Porto Alegre, v. 12, n. 21/22, p.173-225, jan./dez. 2005 
Os casamentos árabes: a recriação de tradições entre imigrantes...

Além do status de casada - como sugere Turner (1974), os ritos marcam a passagem do indivíduo de uma condição social para ocupar outra posição na estrutura social -, o enlace matrimonial significou para ela o reconhecimento de que estaria se tornando "árabe" ao casar com um filho de palestino. Assim, além da aquisição de um novo status, o ritual sobrepõe uma nova posição adquirida nas relações familiares, algo que poderia ser comum aos rituais de casamento - uma separação da família de origem e uma nova morada com o noivo. Todavia, o ritual explicita uma nova condição e reconhecimento de ingresso em valores morais que dizem respeito à origem árabe e que colocam em evidência o lugar e a posição de uma esposa no conjunto desses valores singulares.

Mas como isso se efetiva de forma performática no ritual? O próprio casamento é também uma conversão para a religião muçulmana. Além da entrada e do uso do véu, tão logo o Cheh encerrou a cerimônia, a noiva começou a dançar um repertório de músicas árabes ao som do cantor palestino. Nesse momento, a família faz um círculo em torno dos noivos e passam a dançar a dapca (dança tradicional árabe). A dapca é uma dança tida como típica dos árabes. Dentro dos elementos que constituem o repertório dos costumes performatizados no ritual, essa dança ocupa lugar privilegiado. Indica aspectos significativos da vida social do grupo e ocorre em outras festas, não só em casamentos. Homens dançam entre homens, mulheres dançam entre mulheres. Tal divisão engendra muitas práticas da vida ordinária das pessoas e, inclusive, essa relação é embasada em preceitos religiosos. Basicamente, no salão, a dança é uma coreografia simples, realizada coletivamente. Dois círculos independentes ou que se entrelaçam. Um círculo masculino e outro feminino em que as pessoas que participam dão as mãos levantando ao mesmo tempo a perna direita e, posteriormente, completam dois passos laterais com a perna esquerda na frente. Para que haja um ritmo e sincronicidade na dança das mulheres, um homem mais velho pode puxar o passo 
Denise Fagundes Jardim \& Roberta Peters

inicial e ordenar a roda chamando outras mulheres a se integrar ao círculo, mesmo que seja para aprender a coreografia.

Os círculos da dança de homens e mulheres podem englobar uns aos outros, mas não permitem a mistura entre círculos ou dançar conjuntamente na mesma roda. Outra opção para quem sabe conduzir o passo é dançar no meio da roda. Geralmente, em uma festa ou em uma hena, os noivos são convidados a dançar no centro e o noivo pode também ser levado nas costas de algum parente. Em festas comuns, os homens dançam individualmente no cen-

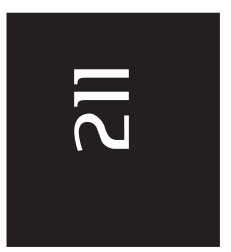
tro da roda. Em Canoas, uma entrevistada relatou que as pessoas "fanáticas" dançam muito, de forma intermitente durante a noite, pois a dança é uma celebração não só pelo caráter alegre da festa, mas porque remete a um sentimento de mesma origem.

Segundo Finnegan (1992), observar e analisar performances pressupõe entender que elas são um modo de linguagem e uma forma de comunicação que constitui uma interação entre um talento individual e uma expectativa cultural. A cerimônia de casamento marcou um ritual da passagem da noiva, simbolizando a morte para sua cultura e o renascimento em outra, a do marido. Pelos seus atos performáticos a noiva estava sendo avaliada pelo público quanto à sua competência em se tornar uma "boa" esposa. Essa concepção de passagem para uma outra "cultura" está relacionada com a visão de mundo do grupo na qual a mulher, quando casa, migra para a parentela do marido. Contudo, o ritual informa sobre as negociações estabelecidas na família para que, mesmo não correspondendo a um padrão tido como tradicional, o casamento possa receber a autorização e o respaldo do grupo. Assim, torna-se interessante acompanhar o processo de negociação familiar que permite que um filho de árabe case com uma brasileira, apesar de o contrário não ter sido verificado entre os entrevistados.

$\mathrm{Na}$ festa de casamento de Michele e Amir alguns pontos sinalizam o reconhecimento de que, nos termos nativos, se trata de 
Os casamentos árabes: a recriação de tradições entre imigrantes...

um casamento misto. E, portanto, há uma forte explicitação, algo pedagógico, do que deveria ser conhecido como um evento tradicional árabe e algo das tradições árabes ao olhar dos "outros". Esse caráter político tem seu momento máximo no ritual quando o patriarca da família que está oferecendo a festa discursa sobre sua condição de imigrante e sua trajetória em distintas localidades brasileiras. Geralmente essa fala evoca a importância de sua família e a relação de irmandade entre brasileiros e palestinos.

Ao congregar as famílias árabes palestinas e os brasileiros a festa cumpre uma dupla função política: recriar um sentimento de solidariedade étnica e manter laços de sociabilidade com os locais, obter um reconhecimento simbólico perante os locais e assegurar um vínculo com os locais, sejam eles convidados da noiva, seus convidados, sejam parentes da noiva (não árabes). Esses laços renovados durante o ritual parecem ser um dos mais eficazes produtores do sentimento de pertença étnica, reiterando e positivando uma origem comum.

Esse discurso da grandiosidade da festa e do mundo árabe, o fato de a festa congregar diferentes famílias de diferentes lugares nos remete a uma idéia de unidade, de solidariedade. Assim, o ritual apresenta esse caráter simbólico, que cria e recria o que é a "família árabe" e uma maneira de celebrar esse ethos. Para além do que é dito em palavras, o clima é de êxtase, de celebração da participação no vasto mundo árabe. Esses são elementos que a festa faz presente e que expressariam esse mundo.

Os casamentos e suas festas: a explicitação de um vasto repertório acerca das tradições

A partir do circuito de festas de casamento árabe estabelecido no Rio Grande do Sul, podemos verificar como esse evento é vivenciado e performatizado pelos imigrantes palestinos e seus 
Denise Fagundes Jardim \& Roberta Peters

filhos brasileiros no Chuí, na capital Porto Alegre e na cidade de Canoas, região metropolitana. Estas últimas localidades em que estão estabelecidas as famílias são tidas, nas redes de relações dos imigrantes, como mais tradicionais e extensas do Estado. Assim, procuramos entender os casamentos árabes a partir das negociações, em seus bastidores, e das festas de casamento como um ritual privilegiado para a compreensão da especificidade da "família árabe", evidenciando aspectos daquilo que os investigados investem e reiteram como sua "tradição".

Mostramos um tema permeado por uma leitura exterior sobre o que seria próprio dos "árabes". De outra parte, apresentamos os casamentos e suas festas como um dos eixos de intensa negociação entre parentes sobre sua inserção e adequação aos modelos possíveis de "família árabe". Tais modelos evocam as pressões e negociações da adequação moral do sujeito às expectativas de um grupo de referência.

Gostaríamos de salientar que as "tradições” são reinventadas e readequadas nesses jogos sociais, produzindo a possibilidade de manutenção de um sentimento de coesão. Mesmo que uma atitude individual seja inesperada, sempre haverá uma possibilidade de negociação em reler o aparentemente díspar como parte desse amplo repertório. Por exemplo, o "casamento errado", que aqui falamos muito pouco, passará por uma intensa negociação em que se avaliam os seus porquês e se tecem considerações sobre os modelos desejáveis. Nesse sentido, não está em jogo a participação individual do sujeito na vida familiar "entre árabes", mas o tema permitirá uma constante familiarização e negociação simbólica sobre as circunstâncias desse modelo desejado e de como reencontrar esse "nós coletivo".

Aparentemente, vista de fora, essa coesão aparece como um arranjo rígido e modelar dos comportamentos individuais. Vistos "de dentro", a partir da etnografia, essa "lógica" é também uma lógica de resolução de conflitos e desentendimentos. Se o "modelo" 
Os casamentos árabes: a recriação de tradições entre imigrantes...

de casamento "entre os seus" parece funcionar tão bem, talvez seja porque ele é uma das chaves de resolução de conflitos familiares, entre gerações, e mediador de expectativas diversas que vão sendo compatibilizadas em situações sociais, como as festas de casamento, desde seus bastidores até o próprio ritual (seu ou de outrem). É um momento de negociação de significados, potencialmente de releitura das disparidades por meio da possibilidade de incorporação.

No que tange ao ritual, as festas de casamento têm uma estrutura que as ordena. Entretanto, as etapas não são fixas e apresentam uma abertura ao contexto no qual ocorre o evento. Por isso, cada caso é um caso. Isto é, cada evento possui um comentário intrínseco sobre os costumes e a tradição revividos nas festas. Podemos pontuar que o evento geralmente ocorre em um clube da capital ou região metropolitana e apresenta um número extenso de convidados (algumas festas já chegaram a reunir 2000 pessoas), incluindo uma longa lista de não-árabes e que expressam a relevância da festa perante os olhares dos "outros".

Entre as principais etapas do ritual está a entrada da(s) noiva(s) junto com o pai ou o irmão, a cerimônia muçulmana celebrada por uma autoridade islâmica, um discurso dos patriarcas da família, um jantar farto e por fim muita dança ao som de uma banda de músicos árabes.

Essa recriação coletiva versa sobre a vida ordinária dos sujeitos e sua visão de mundo, na medida em que o ritual é a expressão pública de um ethos e também um mecanismo produtor de legitimidade e solidariedade étnica. Dotado de um grande poder político, o ritual permite dinamizar as relações entre famílias identificadas como sendo de uma mesma origem e suas relações com os locais. Dessa forma, a grandiosidade da festa, aqui descrita como um exemplo, é verificada pelo número extenso de convidados e informa a importância da família perante um circuito de relações entre os de "dentro" e os de "fora". 
Como sugere Kertzer (2001), os ritos são fundamentais para o processo de associação de indivíduos com entidades simbólicas, como partidos ou, nesse caso, como "nações". Assim, realizam uma função organizacional importante ao diferenciar o grupo-defora do grupo-de-dentro. Essa dramatização da experiência da imigração contribui para reforçar um sentimento de solidariedade étnica na medida em que expressa uma condição social comum.

Entretanto, o leitor pode estar se perguntando sobre a pertinência em falar de ritual e tradição a partir de uma festa de

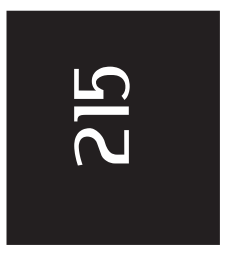
casamento. Como sugere Tambiah (1985), o ritual é uma ação social que se realiza no contexto das visões de mundo partilhadas. Assim, com base nos atos dos sujeitos, pode-se saber tanto ou mais do que aquilo que eles dizem que fazem. Por isso, as características do ritual de casamento estão imbricadas com o contexto maior das normas sociais, das convenções e das práticas culturais. Ao mesmo tempo que o casamento dinamiza as relações familiares, também expressa de forma performática a legitimidade de um padrão familiar de escolha do cônjuge. Mesmo que isso de fato não ocorra, o ritual permite uma releitura que o engloba em sua lógica e o ressemantiza como uma das suas modalidades possíveis.

Neste ensaio, partimos da pressuposição de que em uma situação social ritualizada representa-se e permite-se interpretar as inter-relações humanas. Nesses momentos, as pessoas experienciam e reelaboram questões sociais pautadas pelo grupo. A mensagem do drama reinventa a sua própria estrutura. $\mathrm{O}$ desafio para o cientista social é compreender o que essa experiência humana está comunicando, posto que o ritual é uma forma de representar a realidade.

Na linguagem performática, essas escolhas são encenadas de forma diferenciada. Tal afirmação é embasada na observação participante realizada nesses rituais e por meio dos registros fílmicos entre as famílias Bakri em Porto Alegre, Baja e Zarruq em Canoas e as entrevistas individuais. O casamento entre primos é 
Os casamentos árabes: a recriação de tradições entre imigrantes...

tido como um padrão; entretanto, seu significado é constantemente negociado pelos sujeitos. Dessa forma, as festas informam o quanto autorizada pelos pais foi essa escolha, o que à primeira vista pareceria uma escolha individual, mas que conta com a participação coletiva dos familiares, não só ao financiar a festa (e isso é explicitado, por vezes, durante o ritual). Chama-me a atenção (nos rituais observados em Canoas) que aqueles que o realizam estão traduzindo aos convidados o significados dos atos e de como deveriam ser devidamente interpretados.

Assim, ao abordarmos a questão das festas de casamento estamos interessadas, dentro de uma abordagem antropológica de rituais, em saber como esse evento recria o que é a tradição e como é o sentimento de lealdade étnica embasado numa origem comum. Então, vamos aos fatos.

Tanto no Chuí quanto em Canoas e Porto Alegre, as escolhas matrimoniais pautavam as entrevistas, um gosto por recontar sobre os seus melhores momentos. A importância de falar sobre casamento não era uma exigência do pesquisador, mas um dado de campo. Falar da família para os palestinos é algo fundamental, é a partir da família que as identidades sociais são construídas. Como indica Fargues (1998) o casamento é quase universal entre os árabes, $97 \%$ dos indivíduos contraem ao menos uma união ao longo da vida. Afirma que não é ao acaso dos encontros que a sociedade árabe consegue esse feito, para isso dedica muita energia, visto que aponta a recorrência de um padrão: a filha está destinada para o filho do tio paterno. Mesmo que isso, de fato, não se efetive, o grande investimento afetivo em traçar destinos matrimoniais aos filhos, sobrinhos e solteiros, é uma lógica que abrange diversos aspectos da sua vida, desde as jocosidades com as crianças sobre "quem é seu prometido", até a suspeita de que alguém está estudando para não entrar diretamente no circuito de festas matrimoniais, prorrogando sua exclusão do mercado dos potenciais desposáveis.

Dessa forma, as escolhas matrimoniais e as festas de casamento sempre foram objeto instigante de pesquisa, visto que os

Anos 90, Porto Alegre, v. 12, n. 21/22, p.173-225, jan./dez. 2005 
entrevistados consideram esse evento o mais importante da vida de um árabe. Segundo eles, só há dois momentos em que todos os patrícios se reúnem; um é no casamento, e outro, na morte de um deles. Em ambos os casos, a comparecimento das famílias indica solidariedade e respeito.

Se no Chuí as fitas de casamento não deixavam de ser trocadas entre vizinhas que as olhavam para "tirar idéias" de como se organiza uma festa de casamento, é necessário salientar ainda o quanto se investe não só na festa. Investe-se na sua própria festa, acrescentando elementos novos ao ritual que agreguem mais possibilidades de leitura do que seria árabe e do que seria o caráter das famílias, daquilo que se quer tornar público sobre as famílias que ali se reúnem. Nesse jogo de espelhos que o ritual produz, começamos a observar os filmes com seus protagonistas (no Chuî) e depois as festas, acompanhando suas filmagens (em Canoas). Com base nesse material chegamos a algumas compreensões.

Uma característica importante que se reflete no evento é o tipo de casamento que se quer encenar. A cerimônia apresenta uma encenação diferenciada, caso se trate de um casamento misto ou de primos. Algumas vezes casa-se mais de um casal de primos, filhos de tios da linhagem paterna, em uma mesma cerimônia. Em geral, esses casamentos são os mais grandiosos porque congregam o maior número de pessoas e representam a legitimidade de um padrão e a importância da família em um circuito de relações. Ao contrário, quando o casamento é, do ponto de vista dos investigados, com uma brasileira (misto), o simbolismo do cerimonial que celebra a união da família perde um pouco a força, na medida em que a família da noiva não é de origem palestina. Ele assume um caráter auto-explicativo e deixa de fluir como uma simples e acalorada celebração, embora estejam cientes de que nas festas estarão sob os olhos de outros, pois na maioria dos casamentos há convidados "de fora".

O ritual informa publicamente uma série de negociações estabelecidas entre e dentro das famílias para que, mesmo não

Anos 90, Porto Alegre, v. 12, n. 21/22, p.173-225, jan./dez. 2005

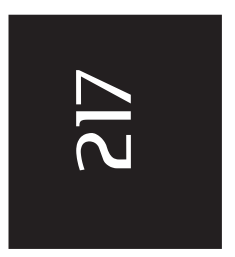


Os casamentos árabes: a recriação de tradições entre imigrantes...

correspondendo a um padrão tido como tradicional, o casamento possa receber a autorização e o respaldo do grupo. Assim, tornase interessante acompanhar o processo de negociação familiar que permite que um filho de árabe case com uma brasileira, apesar de o contrário não ser tão comum entre os entrevistados em Canoas. Talvez devamos pensar nessa recorrência e perceber nisso como um aspecto da explicitação de um arranjo desejável e amplamente conhecido, mais do que estatisticamente uma realidade dos casamentos efetivados.

Concluindo, por meio de uma imersão na realidade dos imigrantes e dos filhos de palestinos no Sul do Brasil, pode-se dizer que aquela afirmação inicial e exterior dos "locais" de que os árabes casam entre si, é uma fala verdadeira, mas que não deve ser simplificada. A acusação de "endogamia" procede em parte dessa interpretação, que mostra a singularidade dos imigrantes. Os casamentos acabam reiterando fronteiras simbólicas mas, mesmo assim, podem “ incluir" novos membros nessa tradição.

Esse circuito de trocas matrimoniais é interessante não só por dar parâmetros ao que seria o "casamento correto" ou "incorreto", mas por ampliar a rede de possibilidades de intercâmbios matrimoniais entre famílias imigrantes, introduzidas e conhecidas a cada novo evento. Por outro lado, as festas reforçam laços de solidariedade e cumplicidade em uma mesma geração, entre primos, e evidenciam os benefícios dessa solidariedade. Ao fim, essas experiências de solidariedade na parentela se tornam conhecidas e amplamente vistas como modelares sobre o mundo dos afetos e dos vínculos entre parentes.

Os casamentos, além de propiciarem um entrelaçamento das famílias imigrantes, inclusive nas festas, colocam em circulação um amplo repertório a respeito da "tradição" e sobre o que significa estar "de acordo com as tradições". Os diversos rituais são recriados em suas diversas etapas: um noivado, um ritual da Hena, o casamento. 
Denise Fagundes Jardim \& Roberta Peters

Como falar sobre a invenção ou recriação de tradições? De um lado, o tema é atual para grupos sociais e pode ajudar a imaginação historiográfica sobre os diferentes sentidos produzidos no jogo social de sua fabricação. Assim como Hobsbawn permitiu aos antropólogos revisitar o fazer etnográfico, a etnografia permite reconsiderar as certezas que propalamos, ao longo do século $\mathrm{XX}$, sobre os termos "cultura", "tradição" e "fronteiras culturais". Se a cultura tem esse efeito classificatório do mundo e das coisas, a etnografia pode evidenciar a operacionalidade de uma lógica própria de atuação e de pensamento. É na ação social que essa lógica é evidenciada e que se reconfigura. Exemplos pontuais nos revelam a fabricação de tradições e o efeito que "estar de acordo com a tradição" sugere aos sujeitos capturados por essa lógica, capturados pelas disposições afetivas ideais do grupo.

Pretendeu-se demonstrar a força desse circuito de casamentos como parte dessa coerção social no sentido de fazer-se presente para os protagonistas e de produzir a possibilidade de novas incorporações. Esses casamentos produzem a possibilidade de incorporações de novos membros, mas também a crença, por parte dos nativos, dos princípios dessa lógica como um princípio de realidade. Para isso, o ritual é fundamental. Ele propicia um momento especial que produz um efeito sobre a coletividade. Tem um efeito pedagógico e público por congregar diversos discursos e "problemas" a resolver. Talvez seja essa uma das razões (sociológicas) que fazem com que os casamentos sejam tão importantes para imigrantes e seus filhos.

Outros aspectos poderiam ser ressaltados. Imagine que os modelos de conduta e destino manejados pelos pais imigrantes não estejam, em virtude da imigração e de toda a ruptura que representa, plenamente conhecidos pelos filhos nascidos e criados no Brasil. Dessa forma, os rituais de casamento dão acesso à importância de uma "tradição" não só aos noivos e potenciais cônjuges, mas a uma coletividade mais abrangente, explicitando novos 
Os casamentos árabes: a recriação de tradições entre imigrantes...

aspectos do que é imaginado como a "nossa tradição". Além disso, como se fossem "cenas", "fatias da vida social", sobrepostas em um mesmo ritual, as festas de casamento revelam o "mundo árabe" a um só tempo para os "seus" e para os "outros" (aqueles que os classificam como "estranhos", "imigrantes"). Essa "fronteira” simbólica que é imaginada em atos cotidianos acaba assumindo contornos mais explícitos e públicos nos rituais de casamento. Desta vez, ao sabor de seus próprios protagonistas.

As festas são um comentário público sobre a identidade palestina como um referencial contemporâneo dessa coletividade. Aspectos relativos à política e ao nacionalismo, que poderiam ser vistos como algo alheio a um ritual entre famílias, tomam relevo e têm um lugar privilegiado, assim como a explicitação da religião muçulmana, do manejo do idioma árabe, na explicitação de uma identidade coletiva.

Todas essas "cenas" aparecem sobrepostas no ritual de casamento, presentes nos momentos que antecedem o encontro das festas, nos seus bastidores e nos registros fílmicos que posteriormente circulam entre as famílias imigrantes. Afinal, o que seria um "casamento árabe?" Certamente a resposta não estaria plenamente respondida se não mostrasse nos bastidores e na "estrutura do ritual" todo o envolvimento e sentimentos investidos, e a força que os anima em delinear modelos ideais e uma coesão social.

\section{Arabian weddings: Palestinian immigrants in the Southern Brazil}

Abstract. This paper gathers the results yielded by two field researches, investigated through the ethnographic methodology; the research, firstly carried out in the city of Chuí, later embraced the residents of the metropolitan area of Porto Alegre. It aims at revealing the efforts made by immigrants in recreating Arabic traditions and in pointing to their common social practices, taking from everyday life the elements that were enhanced to a category of emblematic symbols of the collectivity. Ever since the anthology The invention of traditions, by Ranger and Hobsbawn, in 1983, expatiating on the topic of tradition has become more than a mere act of depiction. The debate will allow us to review the disciplinary frontiers between the realms of history and anthropology and the diverse uses of the term by both fields of

Anos 90, Porto Alegre, v. 12, n. 21/22, p.173-225, jan./dez. 2005 
Denise Fagundes Jardim \& Roberta Peters

knowledge. In this research paper, we will reassume the debate about the creation and recreation of traditions on the basis of the analysis of wedding ceremonies and central importance of the wedding feasts to the creation of social cohesion. We shall bring to evidence some of the feelings related to the creation of such social cohesion and the strategies used by these immigrants aimed at producing enduring notions of their collectivity as having a common origin and tangible destinies.

Keywords: Arabian tradition. Arabian ceremonies. Gender.

\section{Notas}

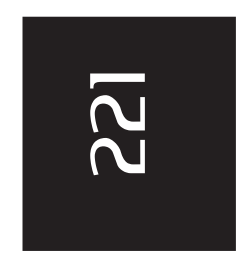

${ }^{1}$ A pesquisa vem sendo desenvolvida como parte do projeto "Palestinos no Extremo sul do Brasil", que propõe um mapeamento das famílias imigrantes palestinas com apoio do programa de iniciação científica (PIBIC/UFRGS). Este trabalho é um desdobramento desse mapeamento, resultando em um trabalho diálogo entre as pesquisadoras sobre o material etnográfico que constitui o projeto de pesquisa no âmbito do mestrado no PPGAS.

${ }^{2}$ Essa é uma das compreensões possíveis sobre a força do nacionalismo, ligada prioritariamente a períodos históricos da construção de Estados-nacionais. Podemos ver o nacionalismo como uma força social mais ampla que prescinde de um projeto político de construção de Estados-nações e, portanto, dotado de múltiplas formas e vozes. Ou, como afirma Gellner (1983), ele aparece na arena política quando a nação está em risco.

${ }^{3}$ As noções de tradição, cultura e identidade não se encontram conceitualmente no mesmo campo de debates e preocupações. Entretanto, esses instrumentos de análise nos colocam um "mesmo" desafio, qual seja, o de evidenciar como os protagonistas produzem consensos e significados, e de como sujeitos concretos participam e encontram-se implicados nos jogos coletivos, negociando tais significados.

${ }^{4}$ A esse respeito, ver Jardim (2000).

${ }^{5}$ O tema não lhes é alheio porque a definição de um "palestino" envolve o reconhecimento internacional de um passaporte, na arena diplomática, e para imigrantes que tem filhos nascidos no Brasil uma possibilidade de retorno familiar que está sempre em risco. Quem teria direito à nacionalidade palestina já passados 50 anos de disputas e redefinições territoriais? A questão é abordada em Jardim (2003).

${ }^{6} \mathrm{O}$ termo ethos remete a uma ampla discussão e constante readequação do termo por parte dos antropólogos. A palavra inicialmente evoca comportamento, costume e um conjunto de valores sociais reconhecidos pelos membros de uma sociedade. Embora tenha sido utilizado como sinônimo de personalidade de base reconhecida pelos membros de uma sociedade, na discussão recente sua definição

Anos 90, Porto Alegre, v. 12, n. 21/22, p.173-225, jan./dez. 2005 
Os casamentos árabes: a recriação de tradições entre imigrantes...

amplia-se (Geertz, 1973) para disposições estéticas, estilos morais e aspectos afetivos estandardizados.

${ }^{7}$ Toda a preparação que antecede uma boda oferece uma maneira de compreender como os imigrantes projetam o exterior e criam o que seja exterior e interior do grupo, por meio da circulação de imagens das festas em jornais locais, bem como pela suntuosidade da festa na cidade de acolhida da boda. Desenvolveremos esse aspecto mais adiante.

${ }^{8}$ Para conhecer o percurso de meus entrevistados, ver Jardim (2000). As viagens à Palestina e a inserção na Sanaud (produzida pela OLP e clube árabe) naquele contexto davam informações iniciais sobre a origem palestina e árabe.

${ }^{9}$ É necessário evocar a literatura antropológica clássica para entender o que as festas fazem na vida social. Como recorda Malinowski (1984), o circuito de festas e de trocas cerimoniais do Kula entre os Trobriand, ou a partir da releitura de Mauss (1974), esses fatos chamam atenção para o caráter simbólico e para o "interesse” (de todos) em instaurar uma dívida como aquilo que incrementa as relações sociais e coloca a obrigação de novas trocas. O interesse fundamental seria o vínculo social e todo o comprometimento emocional em participar dessas relações que são evocados nessas cerimônias.

${ }^{10}$ Ver Sayad (1977) sobre as definições sobre "geração" e as características de cada uma diante da "origem”. Como refere Vitar (2003), é necessário manter uma vigilância sobre esse ideal "natural" acerca da descoberta da "tradição" e "origens" dos imigrantes, e flexibilizar essa rigidez teórica quanto à compreensão de qual geração da imigração que refere a origem.

${ }^{11}$ Provérbio árabe extraído do jornal Maktub, n.9, dez. 1991, editado pelo Centro Cultural Árabe do Rio Grande do Sul, Porto Alegre, RS.

${ }^{12}$ Essa solidariedade entre primos ajuda a sedimentar algumas das considerações nativas acerca da comunidade de mesmo "sangue" e que, em que pesem as distâncias físicas, mantém reciprocidades e um sentimento de ser compreendido, traduzido em um respaldo afetivo de suas decisões e atos simples, como o de partilhar opiniões.

${ }^{13}$ A pesquisa de campo sobre as festas de casamento remete à análise de imagens coletadas em primeira mão pelo uso da câmera fotográfica, pela edição das imagens e fotos pessoais cedidas pelos entrevistados. O consentimento das famílias para o registro e uso desse material fora parte da negociação e entrada em campo estabelecida entre as partes não só sobre as próprias imagens (presentes nesse artigo), mas no que toca às informações coletadas e às falas dos informantes. Nesse percurso, fui muitas vezes confundida com uma jornalista, e por isso ouvia constantemente "podes publicar". Entretanto, sempre foi explicitado o caráter acadêmico do trabalho e o vínculo com a Universidade. Assim, a utilização das fotos remete ao reconhecimento das famílias palestinas de que se trata de uma pesquisa antropológica,

Anos 90, Porto Alegre, v. 12, n. 21/22, p.173-225, jan./dez. 2005 
Denise Fagundes Jardim \& Roberta Peters

embora este seja um dos primeiros textos que circulará como produto de nossos encontros. Portanto, ingressamos em outro tipo de negociação, porque se dará a conhecer algo de minha interpretação sobre sua auto-imagem.

${ }^{14} \mathrm{Um}$ estudo inicial sobre rituais de casamento foi apresentado em Peters (2004).

${ }^{15}$ A esse respeito, ver Dayan-Herzbrun (1995). A autora analisa o lugar central das mulheres na constituição do movimento palestino e nos mostra os novos contornos do uso do véu relacionado à atuação política das mulheres no espaço público. Essa discussão nos aproxima dos inúmeros significados do uso do véu contemporaneamente, dotado de um simbolismo político e, ao mesmo tempo, relacionado à explicitação de valores de um grupo.

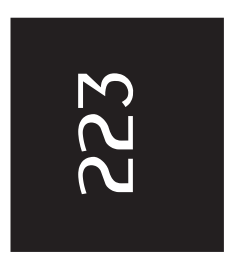

\section{Referências}

BARTH, F. The analysis of culture in complex societies. Ethnos, v.54, n. 3/4, 1989.

BENSÁ, Alban. Da micro-história a uma antropologia crítica. In: Jogos de escala; a experiência da microanálise. Rio de Janeiro: Fundação Getúlio Vargas, 1998. p.39-76.

BOURDIEU, Pierre. Apêndice. O espírito da família. In: Rąões práticas: sobre a teoria da ação. Campinas: Papirus Editora, 1997.

CARNEIRO DA CUNHA, Manuela. Cultura em la política: derechos intelectuales em las poblaciones indígenas y locales. Actas Del IX Congresso de Antropologia de la Federacións de Asociaciones de Antropologia del Estado Español. Barcelona: Institut Catalã d'Antropologia, 2003.

Etnicidade: da cultura residual, mas irredutível. In:

Antropologia do Brasil; mito, história, etnicidade. São Paulo: Brasiliense, 1986.

CLIFFORD, James. Itinerários transculturales. Barcelona: Gedisa, 1997.

DAYAN-HERZBRUN, Sônia. As mulheres e a construção do sentimento nacional palestino. Cadernos Pagú. Fazendo História das Mulheres, Campinas, Núcleo de Estudos de Gênero/UNICAMP, n.4, p.173-186, 1995.

DUMONT, Louis. O individualismo; uma perspectiva antropológica da ideologia moderna. Rio de Janeiro: Rocco, 1985.

FARGUES, Philippe. O mundo árabe: a cidadela doméstica. In: História da família. Portugal: Terramar, 1998.

Anos 90, Porto Alegre, v. 12, n. 21/22, p.173-225, jan./dez. 2005 
Os casamentos árabes: a recriação de tradições entre imigrantes...

FINNEGAN, Ruth. Oral traditions and the verbal arts. London: Routledge, 1992.

GEERTZ, Clifford. The interpretation of cultures. N.Y.: Basil Books, 1973.

. Form and variation in Balinese village structure. In: POTTER; DIAZ; FOSTER (Org). Peasant society. Berkeley: University of California, 1967.

GELLNER, Ernest. Nation and nationalism. London: Basil Blackwell, 1983.

HOBSBAWN, Eric; RANGER, Terence. A invenção das tradições. Rio de Janeiro: Paz e Terra, 1997.

JARDIM, Denise F. Diásporas, viagens e alteridades: as experiências familiares dos palestinos no extremo-sul do Brasil. Horizontes Antropológicos, Porto Alegre, UFRGS/IFCH/PPGAS, ano 6, n.14, 2000.

Palestinos no extremo sul do Brasil: identidade étnica e os mecanismos sociais de produção da etnicidade. Chuí/RS. 2001. Tese (Doutorado) Universidade Federal do Rio de Janeiro, Museu Nacional, Programa de PósGraduação em Antropologia Social, Rio de Janeiro, 2001. (Impresso \& CDROM).

Palestinos: as redefinições de fronteiras e cidadania. Horizontes Antropológicos, Porto Alegre, UFRGS/IFCH/PPGAS, ano 9, n. 19, p.223-243, 2002.

KERTZER, David. Rituais políticos e a transformação do Partido Comunista Italiano. Horizontes Antropológicos, Porto Alegre, UFRGS/IFCH/PPGAS, v. 7, n. 15, p. 15-36, jul. 2001.

MAUSS, Marcel. Ensaio sobre a dádiva. Forma e razão da troca nas sociedades arcaicas. In: Sociologia e Antropologia. São Paulo: EPU, 1974. Vol. II.

MALINOWSKI, Bronislaw. Argonautas do Pacifico Ocidental: um relato do empreendimento e da aventura dos nativos nos arquipélagos da Nova Guiné melanésia. São Paulo: Brasiliense, 1984.

PETERS, Roberta. Palestinos no Sul do Brasil: um estudo sobre grupos minoritários e identidade étnica. In: REUNIÃO DA ABA, FÓRUM DOS JOVENS ANTROPÓLOGOS, 2004, Recife. Anais... Recife, 2004. Resumo.

SAHLINS, Marshall. Dos o tres cosas que sé acerca del concepto de cultura. Revista Colombiana de Antropologia, v.37, p.290-327, ene./ dic. 200.

SAID, Edward. Orientalismo: o Oriente como invenção do Ocidente. São Paulo: Cia das Letras, 1990.

Anos 90, Porto Alegre, v. 12, n. 21/22, p.173-225, jan./dez. 2005 


\section{Denise Fagundes Jardim \& Roberta Peters}

SAYAD, Abdelmalek. Les trois “ages" de l'emigration algerienne em France. Actes de la Recherche, n.17, p.59-79, jun. 1977.

TAMBIAH, Stanley J. Culture, thought, and social action; an anthropological perspective. Cambridge, Mass.: Harvard University Press, 1985.

TURNER, Victor. O processo ritual. Petrópolis: Vozes, 1974.

VITAR, Beatriz Muksdi. Testimonios orales de los descendientes de sirios libaneses en San Miguel de Tucumán (Argentina). Trocadero. Revista de Historia Moderna y Contemporánea, Universidad de Cádiz, Consejo Superior de Investigaciones Científicas, 2003. (Serie La Identificación Étnica).

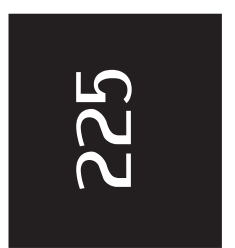

WEBER, Max. Comunidades Étnicas. In: Economia y sociedad. México: Fondo de Cultura Economica, 1968. V.1.

Recebido em 28/05/2005. Aprovado em 31/07/2005. 